Please do not remove this page

RMIT

UNIVERSITY

\title{
Trust, trustworthiness and trust-building in international policing missions
}

Goldsmith, Andrew; Harris, Vandra

https://researchrepository.rmit.edu.au/esploro/outputs/9921858222501341/filesAndLinks?institution=61RMIT_INST\&index=null

Goldsmith, A., \& Harris, V. (2012). Trust, trustworthiness and trust-building in international policing missions. Australian and New Zealand Journal of Criminology, 45(2), 231-254.

https://doi.org/10.1177/0004865812443679

Document Version: Accepted Manuscript

Published Version: https://doi.org/10.1177/0004865812443679

Repository homepage: https://researchrepository.rmit.edu.au

(c) The Author(s) 2012

Downloaded On 2023/04/26 21:47:37 +1000

Please do not remove this page 
Thank you for downloading this document from the RMIT Research Repository.

The RMIT Research Repository is an open access database showcasing the research outputs of RMIT University researchers.

RMIT Research Repository:http://researchbank.rmit.edu.au/

\section{Citation:}

Goldsmith, A and Harris, V 2012, 'Trust, trustworthiness and trust-building in international policing missions', Australian and New Zealand Journal of Criminology, vol. 45, no. 2, pp. 231-254.

See this record in the RMIT Research Repository at:

https://researchbank.rmit.edu.au/view/rmit:16684

Version: Accepted Manuscript

Copyright Statement: (c) The Author(s) 2012

Link to Published Version:

http://dx.doi.org/10.1177/0004865812443679 


\title{
Trust, trustworthiness and trust-building in international policing missions ${ }^{1}$
}

\author{
Andrew Goldsmith and Vandra Harris
}

Trust is widely accepted as being central to domestic police effectiveness and legitimacy. It facilitates dealings between the public and the police, and eases relationships between the individuals within police services. In this article, we argue trust has an equally fundamental role in international policing missions, yet establishing trustworthy policing arrangements is even more difficult for a variety of reasons. We examine a number of these reasons here. The data used is drawn from interviews with Australian police on international deployment in Timor-Leste, Solomon Islands and Papua New Guinea. As the data from case studies indicate, international policing missions often take place in countries with low levels of public trust in the police. For many in these countries, international interventions can be matters of ambivalence or even induce active resistance and resentment. Finding ways of cooperating and collaborating, if not trusting, are fundamental to achieving international policing mission objectives. The article therefore considers some ways in which these missions may minimise distrust and earn trust.

\footnotetext{
${ }^{1}$ The authors wish to thank Charles Hawksley and Gordon Peake and the anonymous reviewers for reading and commenting on earlier drafts of this paper. This research was funded under an Australian Research Council Linkage Grant LP0560643. For correspondence, please contact the firstnamed author at agoldsmi@uow.edu.au
} 
"It is one thing to walk in and everyone says, 'G'day' and shakes your hand and is all smiles, but it is another thing to have the trust of the people." [R02]

"You would have to impress upon them the importance of not killing anybody especially while we were there because we would get the blame and you know if you had any respect for us, you wouldn't do it and that's where that friendship and trust and that built up "[R49]

\section{Introduction}

In this paper, we explore everyday understandings of trust among police peacekeepers and capacity-builders in international police missions. These views inform how international police personnel approach their work in missions, including how they deal with local police counterparts and local people, and how they assess the effectiveness and relevance of what they do. As the objectives of these missions are typically quite ambitious (restoring peace and security; re/building reliable, effective local police forces etc), and often quite challenging at the local level in terms of securing consent and support for change, measures of trust and trustworthiness, we believe, provide insight into the processes by which local consent and commitment to the agendas of these missions are obtained or withheld. As the two opening quotes from our interview-based study of Australian police personnel suggest, establishing trust, while often vital to building effective relationships, can prove elusive.

International peacekeeping was founded upon the principles of impartiality, consent, and use of minimum force (Bellamy et al 2004: 96). In recent years peace mission mandates have changed, becoming more ambitious in scope and focusing more on intra-state conflicts. Police personnel have joined military and civilian personnel in what are sometimes referred to as 'extension of state authority' exercises (Jones et al 2010: 24). The role of international policing in the extension of state authority objectives has thus transformed the notion of policing in the past two decades from being an essentially domestic idea and practice to one of international political and social significance. However, this trend is not entirely new. The role of colonial and European police in matters of general administration and governance has been noted in studies of colonial policing and other policing systems (Dinnen and Braithwaite 2009; Neocleous 2011). In this sense, there are undoubtedly points of continuity between the "export version" of Anglo-American policing and previously enacted models of Western policing. It is not surprising then that international policing missions share the principles of impartiality, consent, and minimum force were also foundational principles of the Anglo-American model (Reiner 2010).

Policing, like many other activities, benefits from cooperation and collaboration with other partners, including members of the community. Obtaining cooperation can be particularly difficult given the nature of police work. When 
this challenge is transferred to a foreign context, the difficulties are greatly magnified. International policing missions frequently intervene in settings in which public trust in police agencies and personnel is historically low or absent what can be considered "low-trust" settings (Fukuyama 1995; Goldsmith 2005). The absence of trust has been identified as one of the key challenges confronting modern peacekeeping operations. According to a recent report, there is "the need to build trust between key players in peacekeeping" (Parker 2010: 4). The report identifies the need to build trust "among the Security Council, Secretariat, troop, and financial contributing countries," and describes this need as "fundamental, achievable, and necessary for effective peacekeeping" (Parker 2010: 6). The absence of trust, as implied here, constitutes a limitation upon the level of cooperation and commitment among participating agencies that is needed to achieve strategic objectives (peace restoration; police reform etc.)

In this paper, we take this point one further step, suggesting that the need to build trust is not limited to 'key players' in the sense of contributing countries and UN bodies. It is also of crucial importance to achieving strategic and tactical success in individual peace operations. In this paper, we propose to explore a number of dimensions of the place of trust in international policing missions. We accept the premise that generally policing is more benign and broadly acceptable if it is undertaken in a genuine trusting environment. We also take the view that as international police peacekeeping is largely charged with restoring security on the ground and, increasingly, ensuring its maintenance over time, those who have experienced or who are experiencing insecurity and likely to be highly distrustful of international agencies and their staff need nonetheless to to be able to trust those agencies and their personnel A critical question then is what conditions would permit an individual or society suffering from insecurity to trust an outside agency or its staff to help them? In short, what facilitates the trustworthiness of that agency or individual?

In section 2, we look at the literature on trust and draw upon that literature to sketch out some of the challenges of dealing with distrust and building trust that might arise in the context of international policing missions involved in peacekeeping and capacity-building tasks. In section 3, we outline the nature of the research undertaken with Australian police personnel who served on these missions which generated interview data from more than 120 interviews, In section 4, this data is drawn upon to extend the analysis, and in particular identify the ways in which trust was a meaningful concept in the work undertaken by these police officers. Section 5 concludes the discussion.

\section{Trusting International Policing Missions}

Trust, for different reasons, is problematic for international policing missions. One reason relates to the nature of policing and police work itself. Police officers typically trade in suspicion and distrust (Reiner 2010; 121-122); they are not inclined to be trusting. In the course of their daily work they must often challenge people in terms of what they are saying or doing; the police intervention may also result in a loss of liberty or privileges, risking the displeasure (or worse) of those deprived. Police work is also uncertain in its 
aims and methods; it exhibits role ambiguity (Thomas 1998). As we will see below, that role ambiguity is even greater when its context is international rather than domestic. In most societies, as maintainers of order, police tend to clash more frequently with members of marginalised communities (Choong 1997). Racial differences frequently are reflected in differentials of police treatment and public respect for the police (Smith 2010). Certain groups have suffered disproportionately from what is sometimes called over-policing and under-policing (OSJI 2009; Skogan 2006; Sharp and Johnson 2009). Being the subject of too much police attention, or failing to obtain their services in moments of need, are negative perceptions that work against the establishment of trusting relationships.

A second reason relates to the particular difficulties of working in foreign settings. As has been also noted in respect of international business relationships, unfamiliarity with local conditions and people tends to work against establishing ready trust (Brenkert 1998). International policing missions in this way resemble other kinds of international strategic alliances, requiring different forms of local cooperation and collaboration. "Trust may be expected to be particularly important in international collaborations, where the negative effects of cultural and physical distance are enhanced and the differences in political, social, and economic contexts may be large" (Zhang and Huxham 2009, 187).

Many mission environments can be classified as low-trust settings, measured in terms of interpersonal trust within the society in question, trust in government aind institutions, and willingness to trust outsiders (Goldsmith 2005). Often past colonial histories and previous experiences of regime-style policing, compound the difficulties international police personnel are likely to face in gaining the confidence of local people (Goldsmith 2003; Dinnen and Braithwaite 2009). Often the average person's view will be of police individually and collectively as abusive, corrupt, or at best, indifferent to their security needs. In short, structural feature of these environments are likely to combine with cultural differences and situational factors to render the task of building trust with local communities and counterparts extremely difficult and perhaps impossible. Dealing with distrust, and building trust, will probably require a lot more than smiles from strangers bearing sweets for the local children. As Tankebe (2009: 1281) noted in relation modern Ghana, "utilitarian factors [will be] important in shaping public cooperation with the police."

A third factor that works against ready trust is the circumstances in which the missions are launched and implemented. Many missions are interventions, whether they be mandated (say by the UN Security Council), or by agreement (sometimes called 'cooperative interventions'). Often as well, there are circumstances of emergency or urgent need that make the pace of intervention quick and therefore limited in terms of any opportunity to plan carefully, to negotiate in advance with affected parties, or to establish clear and shared objectives. Whether the primary mission focus is peacekeeping or capacitybuilding, the fact remains that the interventions are premised upon some kind of inequality between the interveners and the intervenees. It is due to the ascribed 
superiority of the mission in its ability to restore order or re/build local police forces that the mission is present. This inequality is reinforced over time as the superior capacity of the mission in terms of resources and knowledge is demonstrated during the life of the mission.

A failure to negotiate objectives and priorities with local police, and blindness to the persistence of differences of expectations, can result in a lack of local support (Goldsmith and Dinnen 2007). While adequate planning around objectives and collaborative mechanisms at the start is fundamental in building trust, how international personnel then conduct themselves in mission is crucial, and potentially highly destructive of public confidence and trust. As trust implies vulnerability (Montgomery 2008), the excesses or abuses of one party can be extremely damaging to the willingness to trust of the other. Even single acts that violate local expectations can do substantial damage to international trustbuilding agendas. If international police personnel become involved in corruption or sexual exploitation of local people, as has happened on numerous occasions within some UN missions, this can attract negative publicity and local public resentment (Odello 2010). Equally if police fail to restore order promptly after a period of societal conflict, public expectations can be disappointed and result in greater social distance between the international police and local people.

\section{Trust and Trust-building}

Some general observations can be made about trust with application to international policing missions.

Firstly, for the most part, the data discussed here, derived from interviews focusing upon dealings with other individuals, addresses interpersonal rather than institutional trust. However, these concepts are interrelated and both are important from the point of view of meeting the objectives of international policing missions. The relationship between the two is visible in a number of ways. Individual incompetence, for example, can undermine trust in institutions (Thomas 1998). In other words, a police officer who abuses her power can negatively impact upon public perceptions of the organization to which she belongs. On the other hand, there are studies to suggest quite strongly, as one might expect and indeed hope as a member of an international policing mission, that building interpersonal trust locally can contribute to building institutional trust on a wider basis (Tranter and Skrbis 2009). More work is needed to establish under a variety of conditions which measures of interpersonal trust can contribute to trust-building in institutions. However, a recent study among young people in Queensland (Tranter and Skrbis 2009) indicated that having trust in teachers tended to increase institutional trust not just in schools but in other institutions as well, including police, television, and politicians. This finding is certainly consistent with the idea that trust, and more particularly distrust, is often generalised across a range of institutions and settings (Gambetta 1988). For present purposes, while much still remains uncharted in terms of the interrelationship between interpersonal and institutional trust, 
there is adequate evidence of the importance of dealing with interpersonal trust (and distrust) as part of any strategy for improving trust in public institutions.

Secondly, people and cultures differ in terms of their willingness to trust. Some cultures for intrinsic or extrinsic reasons may be less inclined to trust outsiders than others (Putnam 1993; Fukuyama 1995). This variability in willingness to trust will impact differentially in terms of a mission's ability to build trust. Then, trust is relational in character; it only exists when there is an actual or potential relationship between two or more parties. Trust will therefore be influenced in part by the position and attitude of the parties to a particular relationship. If there is actual or perceived imbalance or inequality, that factor can be expected to impact upon the capacity for trust to emerge, and the kinds of relationships that are possible. Power imbalances are not always sufficiently recognised by interveners, and need to be managed as part of any trust-building exercise (Vangen and Huxham 2003). Where there is no previous relationship, establishing trust will require providing reasons for entering a collaboration or providing cooperation. Establishing and meeting local expectations in tangible ways is widely seen as important to taking the first steps towards establishing trust. In other words, successful collaborations will provide a basis for the emergence of trust (Vangen and Huxham 2003).

It is also important to recognise the association between trust and risk and vulnerability. Trust is crucial to enhancing feelings of insecurity. Misztal (1996: 102) describes trust as "a protective mechanism relying on everyday routines, stable reputations and tacit memories, which together push out of modern life fear and uncertainty as well as moral problems". Similarly Luhmann has described trust as a "solution for specific problems of risk" (1988: 95). In these pithy definitions, we can recognise the pertinence of trust to the challenges facing international policing. Paradoxically though, trust itself can also serve as a precondition to taking risks; only when people are confident of their relative safety will they be prepared to undertake certain risky activities. As effecting change is common to both international peacekeeping and capacity-building missions, recognising local feelings of vulnerability on each issue is fundamental to effective trust-building. Sensitivity to past negative experiences at the local level is required:

Where people have little history together, or an erratic history of cooperation mixed with exploitation, or a consistent history of failure to cooperate, people will distrust one another, avoiding collaborative endeavours without guarantees on the other's behaviour (Burt 2001,33)

In terms of being worthy of trust (ie trustworthy), there is considerable consensus about the qualities of an individual or organisation that facilitate trustworthiness. The three most commonly mentioned are: competence, impartiality, and beneficence (Montgomery et al 1998). The first refers to having the relevant skills and capability to assist; the second refers to a lack of bias and a willingness to follow a principled approach to providing assistance, while the third quality refers to acting towards the other person with a view to assisting, 
rather than harming, them. Where one or more of these qualities is seen to be lacking or missing in an individual or an institution, there will be a reluctance to cooperate or collaborate, making the establishment of trust difficult.

Different kinds of, or bases for, trust, need to be considered. Some policing scholars have pointed to motive-based trust. This "turns on whether the police are seen as having the best interests of the community at heart' (Jackson and Bradford 2010: 245). International missions face many difficulties under this standard. They have to be able first to know what those 'best interests' are. This may be no easy matter in the circumstances faced by international policing missions, especially since in the presence of recent conflict there may be many divisions over what this might mean. Furthermore, there are the vexed issues of whether the mission has the mandate and capacity to respond effectively, and more critically, whether it will be appropriate to do so in volatile circumstances. Local divisions within the community, and distrust of outsiders, will mean that showing a commitment to 'the community' will often not be easy.

Another basis for trust has been linked to procedural justice. On this perspective, it is suggested that trust in legal authorities (including police) can emerge from fair and respectful processes, independently (under some conditions at least) of the particular substantive outcomes achieved (Tyler 1990; Hough et al 2010). In other words, treating people fairly can contribute to feelings of trust and confidence in police and other legal authorities; even if the party in question does not get the substantive result he or she was seeking. This approach endorses the value of normative commitment (or cooperation) over instrumental (calculative) cooperation. However, in relation to policing minority communities (Cherney and Murphy 2011) and national communities deeply distrustful of police (Tankebe 2009), where past histories have given little cause for confidence in future different relations between police and these communities, it is far from clear that procedural justice alone can work to build trust and confidence in policing.

Finally, in terms of building or establishing trust, it may be useful to draw on the work of Lane (1998) to distinguish between calculative, cognitive, and normative trust. In effect, this scheme presents three different kinds of trust that might be 'built.' Calculative trust is trust based upon a calculation of costs and benefits of particular courses of action. Costs here include the possibility of deterrence and damage to the reputation of parties. As Child notes (1998: 245), this form of trust is particularly apt in the context of new relationships, and to the formation of new international strategic alliances.

Over time, common ways of thinking may emerge, allowing parties to predict the actions of the other. This is cognitive trust, a sharing of cognitions. Sometimes referred to as knowledge-based trust, it relies on information rather than deterrence. This is a luxury infrequently afforded in the context of most international policing missions, especially at the interpersonal level, where duration of engagements is typically short, often as little as a few weeks or several months. The third, normative trust, "depends on people sharing common values, including a common concept of moral obligation" (Child: 1998: 245). It 
resembles what some scholars call identification-based trust, in which there is a high degree of mutual understanding of each other's wants. Again, the constraints of policing missions make this kind of trust difficult to establish.

A fourth kind, affective trust, is sometimes mentioned in the trust literature. This is based upon emotional ties between people. These are usually built up over time on the basis of effective communication. As Child notes (1998: 246), this kind of trust can be expected rarely in international strategic alliances given issues such as different backgrounds and languages, and the risk of competing objectives.

\section{International Strategic Alliances and Institutional Trust}

In terms of institutional settings for international policing missions, there are useful parallels in seeing these missions as involved in forms of international strategic alliances (ISAs). Both missions and international business ventures share in common the fact that they are inter-agency cooperative arrangements "aimed at pursuing mutual strategic objectives" (Das and Teng 2000: 77). Das and Kumar $(2000 ; 2009)$ look at these arrangements in terms of the presence or absence of commitment and forbearance, the two essential elements of successful inter-partner harmony. The former refers to the degree of interdependency established in the pursuit of shared goals, while the latter relates to "the everpresent need to be restrained, patient, and open-minded in circumstances involving actual or perceived incompatibility of the member firms' actions with expected norms of behaviour" (Das and Kumar 2009:38). The issues of patience between mission partners and the shaky nature of shared commitments is one explored in our data below.

In general terms, ISAs face two challenges. The first is ensuring that there are, in fact, mutual strategic objectives, which in conflict-torn environments can be difficult. As noted earlier, this aspect is often given insufficient attention in the early stages. The second is the fact that the assumptions about "what can be taken for granted" within the alliance are likely to be different, rather than shared (Child 1998, 243). Identifying, and preserving, common goals can be difficult, as we have noted already. In policing as in business, tendencies to compete (or at least resist) exist alongside tendencies to cooperate, and can often undermine trust-building. In business, such alliances tend to be unstable and to fail (Das and Teng 2000). The same can be noted about many previous international peacekeeping and capacity-building initiatives (Chesterman 2004; Jones et al 2010). Studying what makes international strategic alliances in general effective may then pay dividends for international peacekeeping missions.

\section{Falling Short of Trust}

For many reasons then, international policing missions will find themselves in environments in which, at best, trust in them as individuals as well as the 
mission level, is in short supply. This reality poses, as has been already mentioned, the challenge of how, over time, to build trust where it is not present. It also poses questions about dealing with distrust that is preventing improved policing and security from being established (see Goldsmith 2005). Both these goals may take time, or indeed never be achieved in the time available. Early on in missions then, proxies for trust will often be necessary in order to make changes. In extreme life-threatening circumstances (eg humanitarian disasters, ongoing major violence), people at risk may have to 'trust' outsiders because they feel they have little option (Montgomery et al 2008). Under a variety of circumstances of conflict and ignorance, cooperation and compliance therefore can occur without real trust. Commitment over a longer term however is a more difficult accomplishment that may be less responsive to material inducements or emergency provisions.

In the present context, it seems useful to consider a number of 'motivational postures' that can be displayed towards those seeking trust or at least compliance or cooperation (Braithwaite et al 2007). As the prevalence of distrust or at least an absence of trust would suggest, a variety of stances short of trusting cooperation with international policing personnel must be anticipated. In addition to defiance, forms of game playing, resistance, disengagement, cooperation and capitulation can be expected in certain circumstances. Many of the challenges experienced by our respondents can be interpreted in terms of these different postures.

In addition, the wider trajectory of particular missions can be seen often in terms of a shifting menu of different postures displayed by local politicians, police and members of the community. Over time, one could expect the same people to display different dispositions in some cases (though, some may remain fixed), while different segments will be more predisposed to trust than others. As our data discussion below will confirm, much remains unknown regarding how dispositions of defiance and disengagement can be moved in the direction of cooperation and commitment in the contexts we are concerned with here. As seen in other areas of international development and security sector reform, the "quick wins" approach - in the sense of "providing immediately tangible benefits to the population" - in order to "impact positively upon formal and informal political dynamics at all levels" (Stabilisation Unit 2009) suggests that calculative approaches are probably inevitable at the start of most international policing missions as well.

In terms of dealing with distrust, it must be remembered that distrust is not always a bad thing. It can indeed often make sense. The East Timorese who hid in the jungles from the Indonesian police and militia in mid-1999 had good reason to do so. However it is also true that the residue of distrust is typically difficult to overcome: as Gambetta has noted, "deep distrust is very difficult to invalidate through experience, for either it prevents people from engaging in the appropriate kind of social experiment or, worse, it leads to behaviour which bolsters the validity of distrust itself" (1998: 234). This suggests that missions that are not proactive, and that are incapable or unwilling of quickly demonstrating qualities of competent service and impartiality, will continue to 
struggle against what is already a steep gradient in terms of building trust. In our discussion below, we report on what our respondents have said about overcoming residual distrust.

\section{What would a trustworthy international policing mission look like?}

Jackson and Bradford (2010: 245) describe a trustworthy police force in the following terms:

[It] is seen by the public to be effective, to be fair, and to have shared values, interests, and a strong commitment to the local community.... Trust extents beyond narrow public assessments that police perform their duties effectively and efficiently to include a sense that the police understand the needs of the community, that they treat people fairly and with dignity, that they give them information, and that they allow members of the community a voice to highlight local problems.

As we have seen, putting these ideas into practice is never easy - divided communities have long challenged the ideals of modern Western policing (eg Weitzer 1995 on Northern Ireland). It can be expected to be even harder in many international contexts, where unfamiliarity and differences of perspective amplify the underlying challenges of building a trustworthy police. While some indicators emerge from the general trust literature, establishing the conditions that encourage public trust in international policing missions requires further study. Our discussion to this point, and our research discussed below, constitute a modest start in this direction.

\section{The research}

In this section, we draw upon data collected from recorded interviews with more than 120 Australian police who served in peace-keeping and/or capacitybuilding missions in the Solomon Islands, Timor-Leste and Papua New Guinea at some time in the period 2003-20072. When the interview schedules were initially devised, the themes of trust and trust-building were not explicitly addressed or indeed anticipated by the research team. However later, upon examination of the transcripts, we observed that our respondents frequently referred to the concept of trust in relating their experiences with local police and local people during their deployment. It appeared integral to many respondents in terms of making sense of those experiences and in particular, the characteristics of the settings in which they had been tasked to perform peacekeeping and capacity-building roles. In what follows therefore, rather than offering an analysis of data collected with specific research objectives designed around themes relevant to trust, we use the material that emerged in suggestive ways to illuminate some of the themes of trust and trust-building as they affect

\footnotetext{
${ }^{2}$ To maintain confidentiality, participating officers are referred to only by interview number and location of mission/s. The authors acknowledge that further information such as length of service and rank (where applicable) would be interesting to readers; however we feel that inclusion of such information would make officers too easily identifiable.
} 
international policing missions. We see a better understanding of trust from the perspective of the police personnel involved as important in terms of learning from these deployments in order to better prepare future personnel and also in deepening appreciation that the realisation of mission objectives is far more complex an achievement than simply "sending the right people properly equipped and with the right set of instructions on what to do." Understandings of trust take us to the relational, non-technical aspects of international policing missions that have received little systematic attention from either policy-makers or researchers to date.

The three countries covered by the research are small states close to Australia with GDP per capita below USD1,400 (World Bank 2011) and low human development (UN 2011). Approximately even numbers of personnel had served in Timor-Leste (65) and Solomon Islands (68), with a smaller number (35) having served in Papua New Guinea (and 15 in other missions not addressed in the interviews). As will be evident from these totals, approximately half of the participants had served in more than one of these locations. At the time of our interviews, Australian police postings in one location were approximately four months before being transferred elsewhere, though often within one mission, personnel might be moved several times. As our data reveals, this represents a challenge to building trustful relationships and the Australian Federal Police (AFP) has moved to longer postings in these kinds of missions.

The missions to these three nations were diverse in many ways. For the purposes of this paper it is useful to point out, briefly, that Papua New Guinea hosted a short-lived ( 8 month) bilateral mission focused on police capacity building; Solomon Islands continues to host a multilateral mission established in 2003 consisting of regional advisors, police and army forces working first to stabilise and then to build capacity in a range of fields including policing; and Timor-Leste has been host to a series of comprehensive United Nations missions, interspersed with stabilising missions under bilateral auspices, with police performing both in-line and capacity building functions.

As might be expected, each of the settings in which our respondents served provided challenging contexts in which to work. The missions in Timor-Leste since 1999 followed a long and violent independence struggle, and institutions such as the police carried an association with Indonesian rule and thus community perceptions of prejudice and oppression (Kingsbury 2009). As one Australian police officer we interviewed reflected that 'some people ... had a lot of anger, residual anger about the military and the police. There was a perception of corruption and that' (R23). Similarly, a key reason for the establishment of RAMSI in the Solomon Islands was the breakdown of law and order and the paralysis of the country's government during the period 2000 to 2003. Inevitably, this had resulted in severe compromises within the Royal Solomon Islands Police (RSIP) in terms of effectiveness, impartiality and legitimacy. Many of the police were identified with one ethnic grouping (Malaitans) during this period, so that member of other groups felt threatened by the police, even if they were not victimised, which many of them were. Hence it is not surprising that the difficulty of building public trust in these environments 
was discussed by many of the Australian officers who served there and encountered the legacy of past policing experiences.

\section{Our respondents' reflections on trust}

\section{Local attitudes towards international policing missions}

In this part we discuss the willingness of local police and people, as seen through the eyes of our respondents, to show trust to each other as well as to international policing personnel. What was clear from our data was that each of the settings considered could be regarded as low-trust settings afflicted by intercommunal distrust and distrust of authorities, both local and international.

For instance, a number of officers who served in the Solomon Islands reported to us that the community there had little trust for the local police at the outset of the mission, and that their first job was rebuilding this trust: 'we were there to maintain a policing presence and also to help start to rebuild confidence in the police themselves' (R24). Knowing how to capitalise upon the high standing of international personnel in the early stages of interventions in ways that work towards, rather than against, restoring confidence in local police is a key issue facing missions seeking to build institutional trust. Recognising this low willingness to trust, many Australian police reported a proactive approach, in which 'we encouraged people [police] to get out amongst it and regain the community's appreciation and understanding through various strategic initiatives' (R29). These tactics were directly towards trust among local police in the international missions :

whilst on patrol if you were going past the hospital or through the markets, we would always have our windows down and ... the kids would come up and jump on the side of the car. If we had any left over ration packs we would - again it's only community policing - give them to the kids, the lollies, or have toys sent over and try to distribute those as equally as we could. You know we did that to the orphanages as well. We would always stop and chat to people, and again, just community policing. Raising your profile, getting known, getting the trust, getting the respect of the people, and engaging them (R29).

Putting a positive face to policing is surely desirable in these settings; however there is likely to be a significant gap between the levels of distrust that have been built up prior to the intervention and the likely returns of a 'smiles and friendly' approach by itself.

One predictable obstacle international police can face is community distrust towards their local police. According to R43, in the Solomon Islands the communities distrusted the RSIP. If you were aligned with the RSIP, you automatically went into that basket, and they'd pull you aside and say "Why are you talking to Sergeant So and So? He did this, this and this. Why hasn't he been locked up?"' The possibility of this negative influence in large measure will be affected by the extent to which the reformed local police still resemble the previous police, one measure of which is the rehiring of police personnel from 
the previous era. The limits of vetting procedures in terms of rooting out personnel with negative associations to the previous era have been apparent in the case of Timor-Leste as well. Where, as often will be the case, the international police do not control or cannot always veto those readmitted into the reconstituted local police forces, there will be consequences both for how the international police presence is regarded and the prospects for establishing a more trustworthy local police.

As part of a reform push, there will be limits to what can be established in terms of trust between international and local police, especially those in the latter category who face vetting for readmission or who are subject to new methods and changes in the power distribution in the new arrangements. While there are signs in some quarters of an 'international brotherhood' developing among police from different countries (Deflem 2002), there are few signs of a ready affinity here. Our data suggests that the extent of a 'brotherhood' developing across international policing missions and with local police remains limited, and the possibility of its achievement under mission conditions a moot point. As we have noted elsewhere (Goldsmith and Harris 2009), Australian police serving on multilateral peace-keeping missions in Timor-Leste did not always experience this anticipated support from other police forces, and this created a difficult working environment.

Often, international police will have to contend with divisions within local police forces. Distrust among local police will often not be well understood in advance of deployments. It will also affect relations between international and local police. Ethnic tensions within the local police in the Solomon Islands constituted a real difficulty, as described by R55:

\footnotetext{
you could sort of see the underlying mistrust between some of the police, you know, about the Guadis not trusting the Malaitians, but still working alongside them and having jokes with one another and - but you knew sort of deep down they probably didn't really trust them, and some of them held resent from what had happened during the tensions, during the $2000-$ when they had the murders and that ... Now this person hadn't been brought to justice, but they're still working with them. But I guess they knew that while the RAMSI's there ... it's not going to blow up again... [but] they didn't really trust them, or they harboured this resentment
}

In Timor-Leste, divisions emerged along 'Eastern' and 'Western' lines in 2005 and 2006 within the police force as well as the military and other institutions of government, that proved to be highly destructive to mission goals of building public confidence in the local police and its ability to provide an effective, professional service to the people. In Papua New Guinea there were observed divisions between those who wanted change and those who did not. In short, the terrain for trust-building within local police forces is often fractious and contested, a fact that demands better preparation but that must also temper expectations around choice and realisation of mission goals.

As a local police officer, there can be risks in being seen to be 'too close' to international personnel. Reformers always face risks when tackling the status quo, and international policing contexts prove to be no exception. As R45 
reflected on the situation in Papua New Guinea, 'probably one of my biggest concerns [was] what's going to happen with those officers who had supported us [while we were there], when it was obvious that there were other officers out there running their own race and obviously ... didn't want us there and still continued to go about doing what they wanted to do even though we were there.' While changes in administration usually produce some casualties, the uncertainty surrounding the length and success of international policing deployments means that local police officers will be taking major risks to themselves in aligning themselves too closely with mission personnel and objectives. Some will try to 'play both sides of the street' while many will practise forms of non-compliance or provide only limited cooperation. The answer to this dilemma, whatever it may be, clearly lies beyond the competence of individual international police personnel in particular relationships with local police. Ways of supporting local reform-inclined police will be needed that reduce the local risks they face. Securing local high-level endorsement for mission objectives methods is therefore likely to be crucial in the longer-term for allowing trust to develop.

\section{Trust-building with local police}

In this section, we consider the approaches Australian police took to building individual relationships in their work settings. Elsewhere in the development literature scholars have pointed to the critical role that relationships play in capacity building (see Girgis 2007; Kaplan 2000). One of our respondents,R5, echoed this, stating that 'I just found myself being frustrated about [various] things and, of course, it's one thing to say that but then the other side of the equation is to actually capacity build people to think of those things as well, and before you can do that you have to relationship build so they'll at least work with you in doing the processes.'

In their work to influence the practices of local police, Australian police adopted a range of tactics to demonstrate their trustworthiness. Prime amongst these was 'get[ting] your hands dirty' (R54) - that is, showing that they were willing to do the work too. This was particularly relevant in Papua New Guinea, where 'we were supposed to be advisers. We weren't supposed to be helping them with all the paperwork,' but as R24 discovered, 'we felt a bit guilty sitting on our arse doing nothing, so we helped start with some of the paperwork and that's what helps form a better bond and friendship with our counterparts. Because we were prepared to do some of the other work with them not just watch.' of course, as an example of a familiar paradox in capacity-building, by getting involved directly in police work as part of the process of building trust, the goal of building capacity at the local level risks being compromised.

A variety of expectations around relationship building were revealed by the data. It is noteworthy that few respondents appeared to anticipate difficulties in setting up working relationships. It seemed to surprise many of the police we interviewed that they had to build relationships from the ground up with their local colleagues, and 'show you're worthy of respect' (R53). On the other hand, 
several interviewees noted that they couldn't assume that they started from a point of mutual respect. As R16 reflected, 'You can't be expected to win them over in a day because they're very wary of you and the way you are.' R6 conceded that:

there was a lot of resistance from the police at that police station in relation to the people coming in. So it was about breaking down barriers initially you know. And trying to get them all on side, the police we were working with, before we could actually start working with them ... and the way to do that was to create friendships. That is the way I saw it anyway. It certainly wasn't to go in there with a big stick and wave it around, it was to create an environment of trust.

What trust-building meant to our respondents was not an issue we directly sought data on. However some indications emerged from our interviews. The importance of showing, and getting, respect, was mentioned by several respondents. 'It goes back to that thing about gaining their respect, and they won't tell you things unless they respect you' (R40 SI). Such respect was seen as contributing to a personal desire amongst local police to change, with R55 noting, 'I think that when they see how you operate and like I say, if you've got their respect and their trust and they say "Oh yeah, that's - I see why you did that" or they look up to you and they try and emulate you'. It also created a relationship in which respectful critique could be given and responded to, in that 'you go in, look, listen, learn and once you get the relationship going then you might - then you'll be able to offer some suggestions' (R49).

Hardly surprisingly, establishing workable relationships among police could often prove difficult. Just as the relationships with communities were fragile and changeable, relationships with police counterparts could be interrupted or derailed. Here, the impact of short rotations was evident. As R73 pointed out, mistakes could be very costly in terms of achieving the desired capacity building outcomes:

Anyone can ride anyone out for fifteen weeks ${ }^{3}$. If they don't like you, they will just, they are a bit like snails, they will crawl back into their shell, sit and ride the storm out, when you leave, they pop their head out and think, 'right I wonder if I will get on with the next guy?' Understanding that and then coping and dealing with, you know. Making an effort to develop the relationship so that they don't crawl into their shells and turn off while you are there and just ride you out, um is probably the biggest, connecting with them is probably the hardest thing.

A distinction was drawn at times by our respondents between trust in the context of professional relationships and personal relationships. Indeed, the latter was seen by some respondents as a precondition for the former, at least in these settings where there is typically less inclination to draw or see a bright line between the two realms. Our respondents spoke of the importance of building personal relationships with the people with whom they work most closely. In many mission environments, separating professional from personal relationships is not just difficult; it can appear to undermine mission objectives. This personal aspect included finding out about their families and communities,

\footnotetext{
${ }^{3}$ At the time of the interviews (2005-7), officers were generally deployed in three month rotations, followed by a one month break and redeployment to a different posting.
} 
and acknowledging the cultural demands on them - as for example when culture would demand that an officer not confront a community member due to personal ties, which R21 addressed by giving local colleagues the opportunity to step down from particular cases where such conflict arose. Equally important was taking a genuine personal interest in their colleagues - indeed, according to R29, 'you could not have anything but a personal relationship with the RSIP. To try and keep a strictly professional arm's length would not have worked. They are a very personalised people.'

Examples of this included the obvious approach of asking about their family members and their life outside work, as well as less obvious ones like helping a colleague to fill in bureaucratic paperwork needed to enable a family member to travel to Australia for a funeral (R5). In fact, R54 noted that you build trust in Solomon Islands the same way 'you do it anywhere else. Guys you work with, drink with, you talk with, you socialise with ... [and] You don't speak down to them.'

Trying to deal with the blurring of the professional and the personal confronted some respondents with acute dilemmas from time to time. At these moments, the lack of convergence between local and mission values became vivid and a real obstacle to relationship building. This was particularly highlighted in situations whre Australian officers felt forced to choose between building trusting relationships with particular officers and compromising foundational Australian policing values. A vivid example of this was local police wanting to use police missions to gather food, for example by fishing from the police boat, or using police vehicles for personal purposes. R46 explained some of the aspects of this dilemma as follows:

there are a lot of pressures on the police officers to [support their families and kinship groups], and how can you say no? ... Like how do you say, no you can't bring your fish back for your starving family; you'll have to work out some other way. It's just that, those things I found a little bit confronting at times because you have to try and keep the peace I suppose because if you said no, ... they would probably just not have a good relationship with me any more, so you have to draw the line somewhere ... It's very easy for us to say, but for the local police they could never understand why you took that stance.

Learning how to juggle these circumstances is a real operational challenge for many international policing personnel. While there will often be no clear or at least easy answers to these dilemmas, this type of challenge suggests that more could be done to prepare international police to anticipate such challenges arising through cultural awareness training, ethical role-plays and other devices, and to provide them with a range of tactics for managing them.

Having a significant personal relationship with local police could at times enable the assurance that internationally endorsed policing standards were not breached in particular circumstances by local police. R6, who served in Papua New Guinea, explained that once trust was established, there could be quite frank discussions about behavioural change:

there was [a philosophy] to shoot first and ask questions later and we would go to a specific task were there was a possibility that there would be shootings, so and I 
would implore these guys, okay we are not to shoot unless they shoot at us, ... [so] you would have to impress upon them the importance of not killing anybody especially while we were there because we would get the blame and you know if you had any respect for us, you wouldn't do it and that's were that friendship and trust and that built up to a point and they would go okay, well we are not going to kill anyone, we won't shoot anyone because we don't want you to get into trouble. Not because they don't want to do it, because they just didn't want to get us into trouble so okay.

The sustainability of such positive influences is obviously left open to question by this example. It points to the importance of building effective impersonal controls, as well as relying upon personal influence, if longer-term change is to be sustained and sustainable. Despite the difficulties they encountered, respondents stressed the importance of establishing trusting police-public and peer-peer relationships, and the benefits for both sides of working to achieve this. R61 described this situation aptly in terms of the peacekeeping function, stating that a key goal was for local people 'to understand that it was safe again in their community. They were not going to be subject to the terrorisation that they had been subject to by the militant groups, that they could walk the street safely, that they could have confidence again in the police.' This quote is a reminder that the capacity to improve very basic requirements of living and social life remains fundamentally important as a means of establishing some trust or trust-like conditions, especially in the early stages of missions.

\section{Trust building with the local community}

Respondents attempted to break down distrust and scepticism locally by demonstrating that Australian police were friendly and trustworthy. The reasons for building trust were practical as well as noble. Achieving a measure of trust, it was viewed, 'encouraged informants, it encouraged community support, we could go to safety levels, we could get our people amongst the community safely, we could start identifying with honing down where the trouble spots were so it has a lot of strategic gains' (R29). It was well recognised that 'engendering that confidence would then start to bring people back in to report crimes that we could then use to support our mission objectives about removing these key people' (R61).

Part of the trust agenda for international missions is building trust in local institutions. A clear example of this was publicly backing up local police. This could mean confronting local power structures and customary hierarchical relationships in the community. R15 noted that 'some of the local VIPs in the village areas didn't respect the young police officers at all ... in that these guys would be ranting and raving and waving their arms at us [but] we'd say, "no, we're not going anywhere", and that probably helped the local police a little bit, in that we weren't intimidated whereas they might have been.' As noted earlier, when local people are more inclined to seek and trust the services of international police personnel over those of local police, putting the local police forward in order to build their capacity may, for international police, mean incurring the wrath of local people. 
The topic of vetting of recruits to the local police can generate difficulties in terms of local perceptions of the effectiveness and impartiality of international police involved in this important aspect of reconstruction and capacity-building. This can occur when prior vetting of new recruits has not been carried out, or has been done hastily and in an incomplete and ineffective manner. ${ }^{4}$ Senior UN Police officers interviewed by the first author in Timor-Leste in late 2006 expressed the view that the attempt by the government there to 'stand up' the PNTL after the 2006 crisis was proceeding too quickly and that sometimes former senior PNTL officers were being 'waved through' without sufficient regard to their criminal actions during the crisis. This knowledge held by international policing personnel, whether in the form of belief or corroborated fact, as R43's observation above perhaps implies, seems likely to influence how police-police relationships are shaped and operate. Perceptions by international police of defective character among senior local police bode badly in terms of being able to establish positive interpersonal relationships and in terms of pursuing capacity-building objectives.

Importantly, local policing practices also impacted on Australian police's disposition towards their counterparts. Often respondents indicated that trusting them was difficult because of their habits and ways of doing police work. These issues are captured by an officer who had served on several missions: especially in Papua New Guinea and I noticed it more in East Timor, the people had a fear of the police. In PNG ... they [police] had no support from up top or anywhere. There was just no guidance. And they wouldn't work so the people sort of had no respect for the police anyway, but they feared them because they knew that if they did the wrong they would get an absolute flogging. What I noticed over the time was they were starting to lose their fear of the police while we were there because the people knew that while we were there the people wouldn't get a flogging and I notice in East Timor, more to the point, the Australia and New Zealanders were sort of known to be soft, where the Portuguese that were there, knew - they - the locals knew that if they mucked up in front of them there would be a scene. (R17)

This description echoes Mastrofski et al's (2002) notion of a vicious cycle of reciprocal disrespect between police and policed in marginalised communities. It also highlights the reality that redressing such cycles is deeply complex. As the previous quotation suggests, there can be a public safety dividend from the restraining co-presence of international police in such circumstances, but one that is ultimately conditional on their ongoing presence rather than any enduring change within the local police force.

Apparent inconsistencies in how international police personnel are treated by local people and police can undermine confidence in the trustworthiness of

\footnotetext{
${ }^{4}$ It is very difficult to find extensive treatment of the police vetting issue in post-conflict settings in the policy or academic literatures. What occurs in practice too often reflects an international desire to restore local policing responsibility quickly, alongside an influential local interest in ensuring that favoured police are returned as soon as possible to the new institution, irrespective of their past misdeeds. As has been seen in Afghanistan and elsewhere, this can have fatal consequences for international police advisers as well as significant costs for others involved.
} 
locals. Such perceptions often led international police to question their own methods as well as whether the mission goals were indeed appreciated or shared among the local population. This could justify a stance of caution and distrust on the part of international police personnel. Setbacks in the security situation perversely but somewhat understandably appeared to do significant damage to Australian police's trust in the public. R16 reflected that police had to remain on their guard and not assume that they had achieved positive relationships, stating that 'In East Timor one minute, like, they're changing your car tyre and the next minute they're [throwing rocks at] you. So ... you don't trust the people.' This unpredictability or inconsistency could contribute to a stressful environment for officers who were used to being able to judge relationships and the dynamics of policing more accurately in Australia (Goldsmith 2009).

Similarly, in the case of the large-scale civil disturbances in both the Solomon Islands and Timor in 2006, Australian police felt betrayed by the public, in that they were not informed of the pending unrest by any of their informants. R29 discussed this clearly, saying,

The only difficulty came after the riots where you couldn't cross the personal [inaudible] the major balance of society that was rioting and causing problems by stoning you and throwing machetes at you and so on and so forth. So the problem was it was great up to the riots and a significant amount of respect and trust was lost post riots and you never knew who you trusted, therefore it took a long time to rebuild the confidence to trust locals, because during the riots you felt that everybody was against you.

While feelings of betrayal and disappointment were evident, from a mission accomplishment and operational point of view, the question arises of how these feelings influence subsequent dealings with local police and members of the public. A robustness of attitude, informed by a tragic view of the possibilities of change in particular settings, would not seem inappropriate, and even could be seen as desirable or a necessary survival skill for overseas service. Muir (1983, 7) describes the tragic view as "a philosophy which holds that good and bad inhere in each of us, that self-control is an important but not exclusive determinant of man's fate, and that life is meaningful only if we give a damn about others, no matter how such concern hurts." It is, Muir indicates, an antidote to the cynicism that too readily can emerge in police officers. Meeting local distrust with distrust from members of the mission seems certain to further undermine existing relationships and the pursuit of mission objectives. Our respondents, encouragingly, showed little evidence of any resentment impacting on their actions. In dealing with and building trust from the public, they arguably demonstrated both commitment and forbearance. Despite setbacks, they continued to work in this way - if perhaps more warily than before.

Demonstrations of forbearance, as indicated by tolerance of differences of values and approaches, were evident in several of our respondents' answers. Regarding Timor-Leste, R58 spoke of the persistent determination sometimes required to maintain this approach:

I treat people with dignity and respect ... so I don't ever recall thinking "I'll never get through to these people or whatever", there were - of course there were 
moments of frustration where I didn't understand what was going on or things that they wanted were in conflict to things that I needed to do, but that's just you've just got to go with that. You've just got to tolerate that. That's what missions are all about. You're never going to get everything you want, it's never going to happen in the time that you expect it to, and you just have to deal with the contingencies.

A degree of fatalism (a tragic view) is evident in such remarks. An acceptance of difficulty in the job enables work to continue in part through making allowances for perceived shortcomings in the actions and attitudes of others.

Finally, in terms of building trust with local police and local people, it should be noted that the very premises upon which international policing missions are undertaken lend themselves to making it difficult for international policing personnel to respect or trust local police and for local people to willingly trust either their own police or, at times, the international police. After all, it is due to a perceived breakdown in local security capacity or need for significant change that brings international police into these settings, yet very often, local expectations of international police are disappointed for various reasons including insufficient understanding of local circumstances and inadequate resources for dealing effectively with pressing problems. It is not surprising then that many international police will bring with them assumptions about the limited competence of local police as well as the fickleness of local people which can restrict demonstrations of respect towards counterparts and the community.

Starting with the assumption that local officers are generally incompetent, or that the majority of the local population can't be trusted, amount to obstacles to establishing trust. A willingness to trust presumptively indeed may be a prerequisite for securing trust in these circumstances. Against this idea, many of our respondents admitted to holding a generally negative perception of local capacity, identifying their particular counterparts as exceptions to this rule (see Harris 2010). The fact that some respondents were able to distinguish their immediate counterparts from a more generalised negative assessment at least leaves open ways of working constructively with local counterparts. In future efforts to build interpersonal trust, further thought needs to be given to identifying and establishing forms of reciprocity of recognition between international and local people, so that differences that emerge in the life of missions can be managed positively rather than being assumed by one party to be indications of weakness by the other.

\section{Conclusion}

[F]or us it was about re-establishing that community confidence. It is getting them to understand that it was safe again in their community. They were not going to be subject to the terrorisation that they had been subject to by the militant groups, that they could walk the street safely, that they could have confidence again in the police and engendering that confidence would then start to bring people back in to report crimes that we could then use to support our mission objectives about removing these key people (R61). 
As this quotation indicates, ensuring conditions of public safety is fundamental to the enjoyment of individual freedom and cultural identity. Paradoxically, trust in police is often elusive when it is most needed in order to make restoration of public safety achievable. This paper has taken for granted the general value of there being trust in international policing mission settings between mission personnel, local police and people. Our data confirmed that this assumption was widely shared by our respondents. For them in general, it can be said, understandings of trust were crucial to how they approached their work and made sense of their experiences. Nonetheless, as the analysis of the data makes clear, often trust as a characteristic of interpersonal relationships and contacts is an ideal or an illusion, rather than a readily achievable objective under the conditions in which international policing missions are typically engaged.

Given the difficulties of establishing trust, more attention is needed to the conditions that facilitate cooperation and collaboration between international policing personnel and local people and police. In other words, identifying forms of positive engagement short of trusting relationships as well as steps on a path to building trust will prove important to improving how these missions work in particular settings in future. Here, collecting complementary data from local people and police is vital. In our study, we did not capture the views of those local police and members of the community with whom they had contact. A more complete dataset would have sought to include their views in order to explore when trust is extended and what features of missions led to greater trustworthiness. It could also have made it possible to directly gauge the different kinds of motivational dispositions towards peacekeeping and capacitybuilding objectives indicated in some of the recent literature (eg Braithwaite et al 2007).

More could be done to prepare international police personnel to anticipate the range of difficulties reported by our respondents, and to provide them with strategies for coping with them. We have seen that many respondents sought to build trust, yet were disappointed in what was achievable. Therefore, in preparing police personnel for future overseas deployments, efforts are needed to ensure that expectations in terms of local reception and cooperation are not unrealistically high. More preparation in terms of the difficulties of achieving quick change and indeed the changes favoured by international police - the tragic perspective - would be beneficial. Also, the inability to communicate with local people remains a common obstacle. Deficits in communicative competence work against practical accomplishments as well as normative convergence, both crucial to establishing trust.

In short, rather on insisting on trust as a measure of achievement or as a necessary tool for making progress, there is a need for more realism. As noted, the instrumentalism seen in some local attitudes and actions should not be surprising. People habituated to distrusting others need material or at least tangible incentives if calculative trust is to emerge. This does not mean that other forms of trust cannot be developed over time. Changing values as well as practices will require a growing normative commitment among local police and local people if these changes are to be sustainable. There are also likely to be 
limits to how much reliance international personnel put on material incentives if an unhealthy, longer-term dependency is not to be created.

Mission time-scales will continue to work against trust-building. There can be little doubt that short rotations work against establishing effective interpersonal trust, especially cognitive and normative trust. In addition to extending rotations (which Australia has done since our interviews), the process of building trust requires more thinking about how to ensure more 'quick wins' and tangible improvements along the pathway of both peacekeeping and capacity-building. As noted, calculative sensibilities among those international policing personnel are working with have to be expected and managed effectively as part of giving effect to the relationships established. Establishing policing services to the most needy and vulnerable in ways responsive to their concerns must therefore be a priority 'on the ground' as well as in mission policy objectives.

Different means for dealing with distrust are also needed. International policing missions as well as the local institutions they are assisting need to subject themselves to a regulatory environment that is conducive to establishing trust. In short, institutional trust through accountability (eg an independent complaints authority) and measures of responsiveness (eg local level community safety committees) need to be established publicly as part of the strategy of building trust more generally in police-community relations. Responding to distrust implies a number of other steps, including patience and forbearance, and a commitment from the beginning to negotiate expectations around the mission.

In the end though, international policing missions engaged in peacekeeping and capacity-building will continue to take place in environments in which social disengagement from central government is commonplace, and in which broader social trust is scarce or non-existent. It is also the case, as we have seen, that failures at the strategic level (institutional trust) will inevitably impact upon operational achievements (interpersonal trust). Factors that impact upon the trustworthiness of government and political institutions generally, as well as the police in particular, will affect what can be achieved operationally in interpersonal trust in policing mission settings. Given these realities, there is relatively little that international policing missions can achieve by way of building trust and public confidence either quickly or by themselves. We need therefore to recognise the complexity of building trustworthy policing arrangements, important as they remain, and to avoid glib talk about trust until the challenges are better understood and begin to receive broader contextual support. Inevitably, the final responsibility for overcoming disengagement and defiance, and for building trustworthy police agencies, rests mainly with the local, national, regional, and international political systems and the communities in which they are located. 


\section{Bibliography:}

Bellamy, Alex, Williams, Paul and Griffin, Stuart. 2006 Understanding Peacekeeping. Cambridge: Polity Press.

Braithwaite, Valerie, Kristina Murphy, and Monika Reinhart 2007. "Taxation threat, motivational postures, and responsive regulation" Law \& Policy, 29(1), 137-158

Brenkert, George. 1998. "Trust, Morality, and International Business" in Lane and Bachmann, eds, Trust Within and Between Organizations. Oxford: Oxford UP. 273-297

Burt, R. 2001. "Bandwith and echo: trust, information, gossip in social networks" in J Rauch and A Cassella, eds. Networks and Markets, Russell Sage, New York. 30-74

Chase, Susan. 2005. "Narrative Inquiry: Multiple Lenses, Approaches, Voices." In The Sage Handbook of Qualitative Research, eds. Norman Denzin and Yvonna Lincoln. London: Sage.

Child, John. 1998. "Trust and International Strategic Alliances: The Case of SinoForeign Joint Ventures" in Christel Lane and Reinhard Bachmann, eds, Trust Within and Between Organizations: Conceptual Issues and Empirical Applications. Oxford: Oxford UP

Chesterman, Simon. 2004. 'You the People': The United Nations, Transitional Administration, and State-building. New York: Oxford.

Cherney, Adrian and Murphy, Kristina. 2011. "Understanding the contingency of procedural justice outcomes" Policing, [advance access, 22 July 2011]

Choong, Satnam. 1997, Policing as Social Discipline Oxford: Clarendon Press

Das, TK and Rajesh Kumar 2009. "Interpartner harmony in strategic alliances: managing commitment and forbearance" International Journal of Strategic Business Alliances, 1 (1), 24-52

Das, TK and BS Deng 2000. "Instabilities of Strategic Alliances: An Internal Tensions Perspective" Organization Science, 11 (1), 71-101

Deflem, Mathieu. 2002. Policing World Society. Oxford: Oxford UP

Denzin, Norman and Yvonna Lincoln eds. 2005. The Sage Handbook of Qualitative Research. London: Sage.

Dinnen, Sinclair and John Braithwaite. 2009. "Reinventing policing through the prism of the colonial kiap" Policing \& Society, 19 (2), 161-173

Fukuyama, Francis. 1995. Trust: The Social Virtues and the Creation of Prosperity. New York: Free Press.

Gambetta, Diego. 1988. "Can we trust Trust?" in Gambetta, ed. Trust: Making and Breaking Cooperative Relations. Blackwell, Oxford.

Girgis, Mona. 2007. "The Capacity-building Paradox: Using friendship to build capacity in the South." Development in Practice 17(3):353-366.

Goldsmith, Andrew. 2003. "Policing Weak States: Citizen Safety and State Responsibility" Policing \& Society, 13, 1, 1-21

Goldsmith, Andrew. 2005. "Police Reform and the Problem of Trust" Theoretical Criminology, 9(4), 443-470

Goldsmith, Andrew. 2009. "'It wasn't like normal policing: Policing \& Society, 19, 119-133 
Goldsmith, Andrew and Sinclair Dinnen. 2007. "Transnational policebuilding: critical lessons from Timor-Leste and Solomon Islands" Third World Quarterly, 28(6), 1091-1109

Goldsmith, Andrew and Vandra Harris. 2009. "Out of Step: Multilateral police missions, culture and nation-building in Timor-Leste." Conflict, Security and Development 9(2):189-211.

Harris, Vandra. 2010. "Building on Sand? Australian police involvement in international capacity building." Policing and Society 20(1):70-98.

Hough, Mike, Jackson, Jonathan, Bradford, Ben, Myhill, Andy, and Quinton, Paul. 2010. "Procedural Justice, Trust, and Institutional Legitimacy" Policing, 4 (3), 203-110

Jackson, Jonathan and Bradford. 2010. "What is Trust and Confidence in the Police?" Policing, 4 (3), 241-248

Jones, Bruce, Richard Gowan, Jake Sherman (2010), "Excerpts from 'Building on Brahimi: Peacekeeping in an Era of Strategic Uncertainty" in Center for International Cooperation, Robust Peacekeeping: The Politics of Force (New York: CIC, New York University)

Kaplan, Allan. 2000. "Capacity building: shifting the paradigms of practice." Development in Practice 10(3 \& 4):517-526.

Kingsbury, Damien. 2009. East Timor: The Price of Liberty. New York: Palgrave Macmillan.

Lane, Christel. 1998. "Introduction: Theories and issues in the study of trust" in Lane, Christel and Reinhard Bachmann, eds, Trust in and between Organizations: Conceptual Issues and Empirical Applications. Oxford: Oxford University Press, 1-30

Luhmann, Nicholas. 1988. "Familiarity, confidence, trust: Problems and alternatives" In Gambetta, ed. Trust: Making and Breaking Cooperative Relations. Blackwell, Oxford. 94-107

Mastrofski, Stephen, Michael Reisig, and John McCluskey. 2002. "Police Disrespect Toward the Public: An Encounter-Based Analysis" Criminology. 40 (3), 519-552

Misztal, Barbara 1996. Trust in Modern Societies. Cambridge: Polity Press.

Montgomery, Kathleen, Jordens, Christopher, and Little, Miles. 2008. "How vulnerability and trust interact during extreme events: Insights for Human Service Agencies and Organizations" Administration \& Society, 40, 621-644

Muir, William Ker. 1983. "Police and Politics" Criminal Justice Ethics, 2, 3-9

Neocleous, Mark . 2011. "The Police of Civilisation: The War on Terror as Civilizing Offensive" International Political Sociology, 5, 144-159

Odello, Marco. 2010. "Tackling Criminal Acts in Peacekeeping Operations: The Accountability of Peacekeepers" Journal of Conflict \& Security Law, 15(2), 347-391

Open Society Justice Initiative. 2009. Ethnic Profiling in the European Union: Pervasive, Ineffective and Discriminatory (New York: OSJI)

Parker, J Nealin (2010) "Robust Peacekeeping: The Politics of Force Introduction" in Center on International Cooperation, Robust Peacekeeping: The Politics of Force (New York: CIC, New York University) 2-6

Putnam, Robert. 1993. Making Democracy Work. Princeton: Princeton University Press

Reiner, Robert. (2010). The Politics of Police, $4^{\text {th }}$ ed Oxford: Oxford UP. 
Sharp, Elaine and Johnson, Paul. 2009 "Accounting for Variation in Distrust of Local Police" Justice Quarterly, 26 (1) 157-182

Skogan, Wes. 2006. "Asymmetry in the Impact of Encounters with Police" Policing \& Society, 16(2), 99-126

Smith, Sandra. 2010. "Race and Trust" Annual Review of Sociology, 36, 453-475.

Stabilisation Unit. 2009. Stabilisation QIPs Handbook. London: Stabilisation Unit

Tankebe, Justice. 2009. "Public Cooperation with the Police in Ghana: Does Procedural Fairness Matter?" Criminology, 47 (4), 1265-1293.

Thomas, Craig. 1998. "Maintaining and restoring public trust in government agencies and their employees" Administration \& Society, 30, 166-193

Tranter, Bruce, and Skrbis, Zlatko. 2009. "Trust and confidence: A study of young Queenslanders" Australian Journal of Political Science, 44 (4), 659-678

Tyler, Tom. 1990. Why People Obey the Law: Procedural Justice, Legitimacy and Compliance. New Haven: Yale University Press

Weitzer, Ron. 1995. Policing Under Fire: Ethnic Conflict and Police-Community Relations in Northern Ireland Albany: State University of New York Press

United Nations. 2011. Human Development Report 2011: Sustainability and Equity - A Better Future for All. New York: United Nations

Vangen, Siv, and Huxham, Chris. 2003. "Nurturing Collaborative Relations" Building Trust in Interorganizational Collaboration" Journal of Applied Behavioural Science, 39, 5-31

World Bank. 2011. World Development Report. Washington DC: World Bank

Zhang, Ying and Huxham, Chris. 2009. "Identity Construction and Trust Building in Developing International Collaborations" Journal of Applied Behavioral Science, 45, 186-211 
t
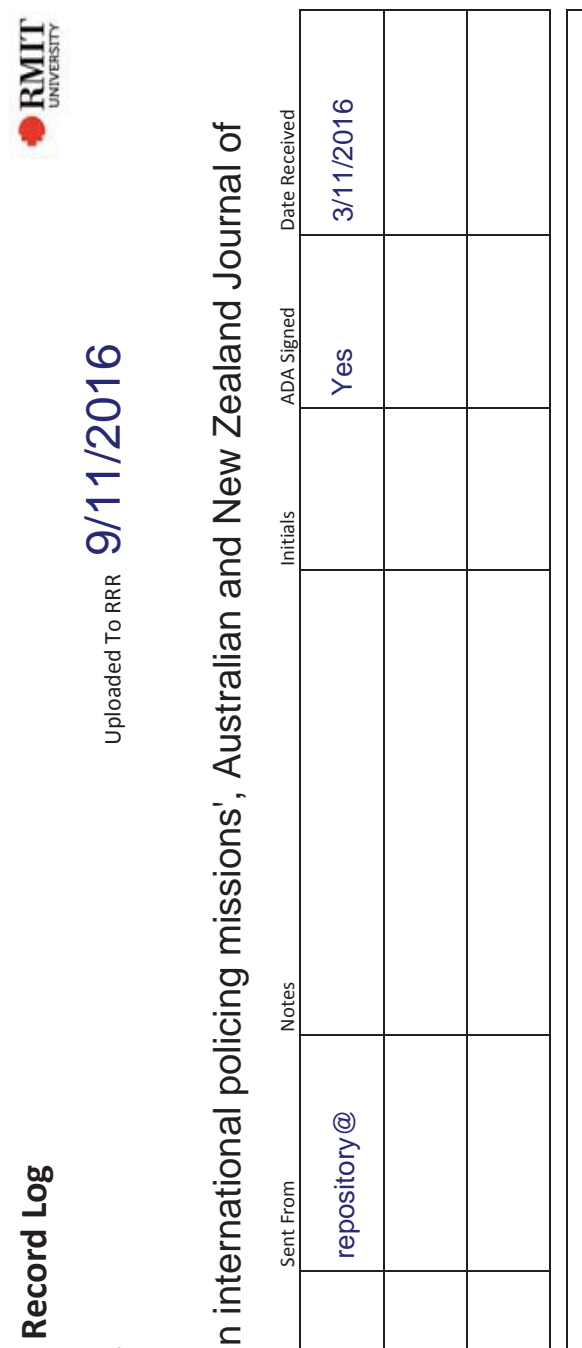

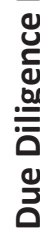




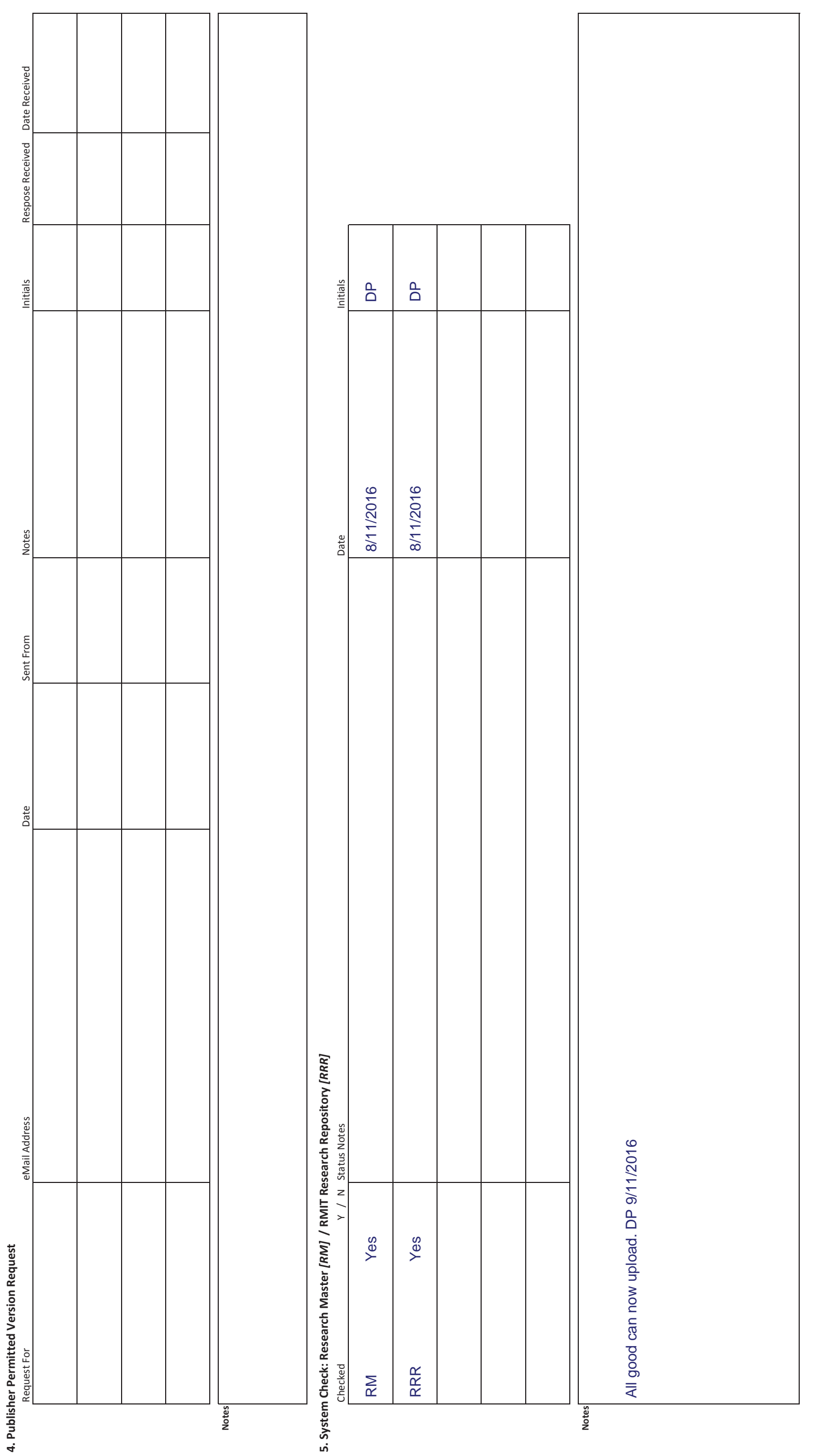




\title{
Trust, trustworthiness and trust-building in international policing missions ${ }^{1}$
}

\author{
Andrew Goldsmith and Vandra Harris
}

Trust is widely accepted as being central to domestic police effectiveness and legitimacy. It facilitates dealings between the public and the police, and eases relationships between the individuals within police services. In this article, we argue trust has an equally fundamental role in international policing missions, yet establishing trustworthy policing arrangements is even more difficult for a variety of reasons. We examine a number of these reasons here. The data used is drawn from interviews with Australian police on international deployment in Timor-Leste, Solomon Islands and Papua New Guinea. As the data from case studies indicate, international policing missions often take place in countries with low levels of public trust in the police. For many in these countries, international interventions can be matters of ambivalence or even induce active resistance and resentment. Finding ways of cooperating and collaborating, if not trusting, are fundamental to achieving international policing mission objectives. The article therefore considers some ways in which these missions may minimise distrust and earn trust.

\footnotetext{
${ }^{1}$ The authors wish to thank Charles Hawksley and Gordon Peake and the anonymous reviewers for reading and commenting on earlier drafts of this paper. This research was funded under an Australian Research Council Linkage Grant LP0560643. For correspondence, please contact the firstnamed author at agoldsmi@uow.edu.au
} 
"It is one thing to walk in and everyone says, 'G'day' and shakes your hand and is all smiles, but it is another thing to have the trust of the people." [R02]

"You would have to impress upon them the importance of not killing anybody especially while we were there because we would get the blame and you know if you had any respect for us, you wouldn't do it and that's where that friendship and trust and that built up "[R49]

\section{Introduction}

In this paper, we explore everyday understandings of trust among police peacekeepers and capacity-builders in international police missions. These views inform how international police personnel approach their work in missions, including how they deal with local police counterparts and local people, and how they assess the effectiveness and relevance of what they do. As the objectives of these missions are typically quite ambitious (restoring peace and security; re/building reliable, effective local police forces etc), and often quite challenging at the local level in terms of securing consent and support for change, measures of trust and trustworthiness, we believe, provide insight into the processes by which local consent and commitment to the agendas of these missions are obtained or withheld. As the two opening quotes from our interview-based study of Australian police personnel suggest, establishing trust, while often vital to building effective relationships, can prove elusive.

International peacekeeping was founded upon the principles of impartiality, consent, and use of minimum force (Bellamy et al 2004: 96). In recent years peace mission mandates have changed, becoming more ambitious in scope and focusing more on intra-state conflicts. Police personnel have joined military and civilian personnel in what are sometimes referred to as 'extension of state authority' exercises (Jones et al 2010: 24). The role of international policing in the extension of state authority objectives has thus transformed the notion of policing in the past two decades from being an essentially domestic idea and practice to one of international political and social significance. However, this trend is not entirely new. The role of colonial and European police in matters of general administration and governance has been noted in studies of colonial policing and other policing systems (Dinnen and Braithwaite 2009; Neocleous 2011). In this sense, there are undoubtedly points of continuity between the "export version" of Anglo-American policing and previously enacted models of Western policing. It is not surprising then that international policing missions share the principles of impartiality, consent, and minimum force were also foundational principles of the Anglo-American model (Reiner 2010).

Policing, like many other activities, benefits from cooperation and collaboration with other partners, including members of the community. Obtaining cooperation can be particularly difficult given the nature of police work. When 
this challenge is transferred to a foreign context, the difficulties are greatly magnified. International policing missions frequently intervene in settings in which public trust in police agencies and personnel is historically low or absent what can be considered "low-trust" settings (Fukuyama 1995; Goldsmith 2005). The absence of trust has been identified as one of the key challenges confronting modern peacekeeping operations. According to a recent report, there is "the need to build trust between key players in peacekeeping" (Parker 2010: 4). The report identifies the need to build trust "among the Security Council, Secretariat, troop, and financial contributing countries," and describes this need as "fundamental, achievable, and necessary for effective peacekeeping" (Parker 2010: 6). The absence of trust, as implied here, constitutes a limitation upon the level of cooperation and commitment among participating agencies that is needed to achieve strategic objectives (peace restoration; police reform etc.)

In this paper, we take this point one further step, suggesting that the need to build trust is not limited to 'key players' in the sense of contributing countries and UN bodies. It is also of crucial importance to achieving strategic and tactical success in individual peace operations. In this paper, we propose to explore a number of dimensions of the place of trust in international policing missions. We accept the premise that generally policing is more benign and broadly acceptable if it is undertaken in a genuine trusting environment. We also take the view that as international police peacekeeping is largely charged with restoring security on the ground and, increasingly, ensuring its maintenance over time, those who have experienced or who are experiencing insecurity and likely to be highly distrustful of international agencies and their staff need nonetheless to to be able to trust those agencies and their personnel A critical question then is what conditions would permit an individual or society suffering from insecurity to trust an outside agency or its staff to help them? In short, what facilitates the trustworthiness of that agency or individual?

In section 2, we look at the literature on trust and draw upon that literature to sketch out some of the challenges of dealing with distrust and building trust that might arise in the context of international policing missions involved in peacekeeping and capacity-building tasks. In section 3, we outline the nature of the research undertaken with Australian police personnel who served on these missions which generated interview data from more than 120 interviews, In section 4, this data is drawn upon to extend the analysis, and in particular identify the ways in which trust was a meaningful concept in the work undertaken by these police officers. Section 5 concludes the discussion.

\section{Trusting International Policing Missions}

Trust, for different reasons, is problematic for international policing missions. One reason relates to the nature of policing and police work itself. Police officers typically trade in suspicion and distrust (Reiner 2010; 121-122); they are not inclined to be trusting. In the course of their daily work they must often challenge people in terms of what they are saying or doing; the police intervention may also result in a loss of liberty or privileges, risking the displeasure (or worse) of those deprived. Police work is also uncertain in its 
aims and methods; it exhibits role ambiguity (Thomas 1998). As we will see below, that role ambiguity is even greater when its context is international rather than domestic. In most societies, as maintainers of order, police tend to clash more frequently with members of marginalised communities (Choong 1997). Racial differences frequently are reflected in differentials of police treatment and public respect for the police (Smith 2010). Certain groups have suffered disproportionately from what is sometimes called over-policing and under-policing (OSJI 2009; Skogan 2006; Sharp and Johnson 2009). Being the subject of too much police attention, or failing to obtain their services in moments of need, are negative perceptions that work against the establishment of trusting relationships.

A second reason relates to the particular difficulties of working in foreign settings. As has been also noted in respect of international business relationships, unfamiliarity with local conditions and people tends to work against establishing ready trust (Brenkert 1998). International policing missions in this way resemble other kinds of international strategic alliances, requiring different forms of local cooperation and collaboration. "Trust may be expected to be particularly important in international collaborations, where the negative effects of cultural and physical distance are enhanced and the differences in political, social, and economic contexts may be large" (Zhang and Huxham 2009, 187).

Many mission environments can be classified as low-trust settings, measured in terms of interpersonal trust within the society in question, trust in government aind institutions, and willingness to trust outsiders (Goldsmith 2005). Often past colonial histories and previous experiences of regime-style policing, compound the difficulties international police personnel are likely to face in gaining the confidence of local people (Goldsmith 2003; Dinnen and Braithwaite 2009). Often the average person's view will be of police individually and collectively as abusive, corrupt, or at best, indifferent to their security needs. In short, structural feature of these environments are likely to combine with cultural differences and situational factors to render the task of building trust with local communities and counterparts extremely difficult and perhaps impossible. Dealing with distrust, and building trust, will probably require a lot more than smiles from strangers bearing sweets for the local children. As Tankebe (2009: 1281) noted in relation modern Ghana, "utilitarian factors [will be] important in shaping public cooperation with the police."

A third factor that works against ready trust is the circumstances in which the missions are launched and implemented. Many missions are interventions, whether they be mandated (say by the UN Security Council), or by agreement (sometimes called 'cooperative interventions'). Often as well, there are circumstances of emergency or urgent need that make the pace of intervention quick and therefore limited in terms of any opportunity to plan carefully, to negotiate in advance with affected parties, or to establish clear and shared objectives. Whether the primary mission focus is peacekeeping or capacitybuilding, the fact remains that the interventions are premised upon some kind of inequality between the interveners and the intervenees. It is due to the ascribed 
superiority of the mission in its ability to restore order or re/build local police forces that the mission is present. This inequality is reinforced over time as the superior capacity of the mission in terms of resources and knowledge is demonstrated during the life of the mission.

A failure to negotiate objectives and priorities with local police, and blindness to the persistence of differences of expectations, can result in a lack of local support (Goldsmith and Dinnen 2007). While adequate planning around objectives and collaborative mechanisms at the start is fundamental in building trust, how international personnel then conduct themselves in mission is crucial, and potentially highly destructive of public confidence and trust. As trust implies vulnerability (Montgomery 2008), the excesses or abuses of one party can be extremely damaging to the willingness to trust of the other. Even single acts that violate local expectations can do substantial damage to international trustbuilding agendas. If international police personnel become involved in corruption or sexual exploitation of local people, as has happened on numerous occasions within some UN missions, this can attract negative publicity and local public resentment (Odello 2010). Equally if police fail to restore order promptly after a period of societal conflict, public expectations can be disappointed and result in greater social distance between the international police and local people.

\section{Trust and Trust-building}

Some general observations can be made about trust with application to international policing missions.

Firstly, for the most part, the data discussed here, derived from interviews focusing upon dealings with other individuals, addresses interpersonal rather than institutional trust. However, these concepts are interrelated and both are important from the point of view of meeting the objectives of international policing missions. The relationship between the two is visible in a number of ways. Individual incompetence, for example, can undermine trust in institutions (Thomas 1998). In other words, a police officer who abuses her power can negatively impact upon public perceptions of the organization to which she belongs. On the other hand, there are studies to suggest quite strongly, as one might expect and indeed hope as a member of an international policing mission, that building interpersonal trust locally can contribute to building institutional trust on a wider basis (Tranter and Skrbis 2009). More work is needed to establish under a variety of conditions which measures of interpersonal trust can contribute to trust-building in institutions. However, a recent study among young people in Queensland (Tranter and Skrbis 2009) indicated that having trust in teachers tended to increase institutional trust not just in schools but in other institutions as well, including police, television, and politicians. This finding is certainly consistent with the idea that trust, and more particularly distrust, is often generalised across a range of institutions and settings (Gambetta 1988). For present purposes, while much still remains uncharted in terms of the interrelationship between interpersonal and institutional trust, 
there is adequate evidence of the importance of dealing with interpersonal trust (and distrust) as part of any strategy for improving trust in public institutions.

Secondly, people and cultures differ in terms of their willingness to trust. Some cultures for intrinsic or extrinsic reasons may be less inclined to trust outsiders than others (Putnam 1993; Fukuyama 1995). This variability in willingness to trust will impact differentially in terms of a mission's ability to build trust. Then, trust is relational in character; it only exists when there is an actual or potential relationship between two or more parties. Trust will therefore be influenced in part by the position and attitude of the parties to a particular relationship. If there is actual or perceived imbalance or inequality, that factor can be expected to impact upon the capacity for trust to emerge, and the kinds of relationships that are possible. Power imbalances are not always sufficiently recognised by interveners, and need to be managed as part of any trust-building exercise (Vangen and Huxham 2003). Where there is no previous relationship, establishing trust will require providing reasons for entering a collaboration or providing cooperation. Establishing and meeting local expectations in tangible ways is widely seen as important to taking the first steps towards establishing trust. In other words, successful collaborations will provide a basis for the emergence of trust (Vangen and Huxham 2003).

It is also important to recognise the association between trust and risk and vulnerability. Trust is crucial to enhancing feelings of insecurity. Misztal (1996: 102) describes trust as "a protective mechanism relying on everyday routines, stable reputations and tacit memories, which together push out of modern life fear and uncertainty as well as moral problems". Similarly Luhmann has described trust as a "solution for specific problems of risk" (1988: 95). In these pithy definitions, we can recognise the pertinence of trust to the challenges facing international policing. Paradoxically though, trust itself can also serve as a precondition to taking risks; only when people are confident of their relative safety will they be prepared to undertake certain risky activities. As effecting change is common to both international peacekeeping and capacity-building missions, recognising local feelings of vulnerability on each issue is fundamental to effective trust-building. Sensitivity to past negative experiences at the local level is required:

Where people have little history together, or an erratic history of cooperation mixed with exploitation, or a consistent history of failure to cooperate, people will distrust one another, avoiding collaborative endeavours without guarantees on the other's behaviour (Burt 2001, 33)

In terms of being worthy of trust (ie trustworthy), there is considerable consensus about the qualities of an individual or organisation that facilitate trustworthiness. The three most commonly mentioned are: competence, impartiality, and beneficence (Montgomery et al 1998). The first refers to having the relevant skills and capability to assist; the second refers to a lack of bias and a willingness to follow a principled approach to providing assistance, while the third quality refers to acting towards the other person with a view to assisting, 
rather than harming, them. Where one or more of these qualities is seen to be lacking or missing in an individual or an institution, there will be a reluctance to cooperate or collaborate, making the establishment of trust difficult.

Different kinds of, or bases for, trust, need to be considered. Some policing scholars have pointed to motive-based trust. This "turns on whether the police are seen as having the best interests of the community at heart' (Jackson and Bradford 2010: 245). International missions face many difficulties under this standard. They have to be able first to know what those 'best interests' are. This may be no easy matter in the circumstances faced by international policing missions, especially since in the presence of recent conflict there may be many divisions over what this might mean. Furthermore, there are the vexed issues of whether the mission has the mandate and capacity to respond effectively, and more critically, whether it will be appropriate to do so in volatile circumstances. Local divisions within the community, and distrust of outsiders, will mean that showing a commitment to 'the community' will often not be easy.

Another basis for trust has been linked to procedural justice. On this perspective, it is suggested that trust in legal authorities (including police) can emerge from fair and respectful processes, independently (under some conditions at least) of the particular substantive outcomes achieved (Tyler 1990; Hough et al 2010). In other words, treating people fairly can contribute to feelings of trust and confidence in police and other legal authorities; even if the party in question does not get the substantive result he or she was seeking. This approach endorses the value of normative commitment (or cooperation) over instrumental (calculative) cooperation. However, in relation to policing minority communities (Cherney and Murphy 2011) and national communities deeply distrustful of police (Tankebe 2009), where past histories have given little cause for confidence in future different relations between police and these communities, it is far from clear that procedural justice alone can work to build trust and confidence in policing.

Finally, in terms of building or establishing trust, it may be useful to draw on the work of Lane (1998) to distinguish between calculative, cognitive, and normative trust. In effect, this scheme presents three different kinds of trust that might be 'built.' Calculative trust is trust based upon a calculation of costs and benefits of particular courses of action. Costs here include the possibility of deterrence and damage to the reputation of parties. As Child notes (1998: 245), this form of trust is particularly apt in the context of new relationships, and to the formation of new international strategic alliances.

Over time, common ways of thinking may emerge, allowing parties to predict the actions of the other. This is cognitive trust, a sharing of cognitions. Sometimes referred to as knowledge-based trust, it relies on information rather than deterrence. This is a luxury infrequently afforded in the context of most international policing missions, especially at the interpersonal level, where duration of engagements is typically short, often as little as a few weeks or several months. The third, normative trust, "depends on people sharing common values, including a common concept of moral obligation” (Child: 1998: 245). It 
resembles what some scholars call identification-based trust, in which there is a high degree of mutual understanding of each other's wants. Again, the constraints of policing missions make this kind of trust difficult to establish.

A fourth kind, affective trust, is sometimes mentioned in the trust literature. This is based upon emotional ties between people. These are usually built up over time on the basis of effective communication. As Child notes (1998: 246), this kind of trust can be expected rarely in international strategic alliances given issues such as different backgrounds and languages, and the risk of competing objectives.

\section{International Strategic Alliances and Institutional Trust}

In terms of institutional settings for international policing missions, there are useful parallels in seeing these missions as involved in forms of international strategic alliances (ISAs). Both missions and international business ventures share in common the fact that they are inter-agency cooperative arrangements "aimed at pursuing mutual strategic objectives" (Das and Teng 2000: 77). Das and Kumar $(2000 ; 2009)$ look at these arrangements in terms of the presence or absence of commitment and forbearance, the two essential elements of successful inter-partner harmony. The former refers to the degree of interdependency established in the pursuit of shared goals, while the latter relates to "the everpresent need to be restrained, patient, and open-minded in circumstances involving actual or perceived incompatibility of the member firms' actions with expected norms of behaviour" (Das and Kumar 2009:38). The issues of patience between mission partners and the shaky nature of shared commitments is one explored in our data below.

In general terms, ISAs face two challenges. The first is ensuring that there are, in fact, mutual strategic objectives, which in conflict-torn environments can be difficult. As noted earlier, this aspect is often given insufficient attention in the early stages. The second is the fact that the assumptions about "what can be taken for granted" within the alliance are likely to be different, rather than shared (Child 1998, 243). Identifying, and preserving, common goals can be difficult, as we have noted already. In policing as in business, tendencies to compete (or at least resist) exist alongside tendencies to cooperate, and can often undermine trust-building. In business, such alliances tend to be unstable and to fail (Das and Teng 2000). The same can be noted about many previous international peacekeeping and capacity-building initiatives (Chesterman 2004; Jones et al 2010). Studying what makes international strategic alliances in general effective may then pay dividends for international peacekeeping missions.

\section{Falling Short of Trust}

For many reasons then, international policing missions will find themselves in environments in which, at best, trust in them as individuals as well as the 
mission level, is in short supply. This reality poses, as has been already mentioned, the challenge of how, over time, to build trust where it is not present. It also poses questions about dealing with distrust that is preventing improved policing and security from being established (see Goldsmith 2005). Both these goals may take time, or indeed never be achieved in the time available. Early on in missions then, proxies for trust will often be necessary in order to make changes. In extreme life-threatening circumstances (eg humanitarian disasters, ongoing major violence), people at risk may have to 'trust' outsiders because they feel they have little option (Montgomery et al 2008). Under a variety of circumstances of conflict and ignorance, cooperation and compliance therefore can occur without real trust. Commitment over a longer term however is a more difficult accomplishment that may be less responsive to material inducements or emergency provisions.

In the present context, it seems useful to consider a number of 'motivational postures' that can be displayed towards those seeking trust or at least compliance or cooperation (Braithwaite et al 2007). As the prevalence of distrust or at least an absence of trust would suggest, a variety of stances short of trusting cooperation with international policing personnel must be anticipated. In addition to defiance, forms of game playing, resistance, disengagement, cooperation and capitulation can be expected in certain circumstances. Many of the challenges experienced by our respondents can be interpreted in terms of these different postures.

In addition, the wider trajectory of particular missions can be seen often in terms of a shifting menu of different postures displayed by local politicians, police and members of the community. Over time, one could expect the same people to display different dispositions in some cases (though, some may remain fixed), while different segments will be more predisposed to trust than others. As our data discussion below will confirm, much remains unknown regarding how dispositions of defiance and disengagement can be moved in the direction of cooperation and commitment in the contexts we are concerned with here. As seen in other areas of international development and security sector reform, the "quick wins" approach - in the sense of "providing immediately tangible benefits to the population" - in order to "impact positively upon formal and informal political dynamics at all levels" (Stabilisation Unit 2009) suggests that calculative approaches are probably inevitable at the start of most international policing missions as well.

In terms of dealing with distrust, it must be remembered that distrust is not always a bad thing. It can indeed often make sense. The East Timorese who hid in the jungles from the Indonesian police and militia in mid-1999 had good reason to do so. However it is also true that the residue of distrust is typically difficult to overcome: as Gambetta has noted, "deep distrust is very difficult to invalidate through experience, for either it prevents people from engaging in the appropriate kind of social experiment or, worse, it leads to behaviour which bolsters the validity of distrust itself" (1998: 234). This suggests that missions that are not proactive, and that are incapable or unwilling of quickly demonstrating qualities of competent service and impartiality, will continue to 
struggle against what is already a steep gradient in terms of building trust. In our discussion below, we report on what our respondents have said about overcoming residual distrust.

What would a trustworthy international policing mission look like?

Jackson and Bradford (2010: 245) describe a trustworthy police force in the following terms:

[It] is seen by the public to be effective, to be fair, and to have shared values, interests, and a strong commitment to the local community.... Trust extents beyond narrow public assessments that police perform their duties effectively and efficiently to include a sense that the police understand the needs of the community, that they treat people fairly and with dignity, that they give them information, and that they allow members of the community a voice to highlight local problems.

As we have seen, putting these ideas into practice is never easy - divided communities have long challenged the ideals of modern Western policing (eg Weitzer 1995 on Northern Ireland). It can be expected to be even harder in many international contexts, where unfamiliarity and differences of perspective amplify the underlying challenges of building a trustworthy police. While some indicators emerge from the general trust literature, establishing the conditions that encourage public trust in international policing missions requires further study. Our discussion to this point, and our research discussed below, constitute a modest start in this direction.

\section{The research}

In this section, we draw upon data collected from recorded interviews with more than 120 Australian police who served in peace-keeping and/or capacitybuilding missions in the Solomon Islands, Timor-Leste and Papua New Guinea at some time in the period 2003-20072. When the interview schedules were initially devised, the themes of trust and trust-building were not explicitly addressed or indeed anticipated by the research team. However later, upon examination of the transcripts, we observed that our respondents frequently referred to the concept of trust in relating their experiences with local police and local people during their deployment. It appeared integral to many respondents in terms of making sense of those experiences and in particular, the characteristics of the settings in which they had been tasked to perform peacekeeping and capacity-building roles. In what follows therefore, rather than offering an analysis of data collected with specific research objectives designed around themes relevant to trust, we use the material that emerged in suggestive ways to illuminate some of the themes of trust and trust-building as they affect

\footnotetext{
${ }^{2}$ To maintain confidentiality, participating officers are referred to only by interview number and location of mission/s. The authors acknowledge that further information such as length of service and rank (where applicable) would be interesting to readers; however we feel that inclusion of such information would make officers too easily identifiable.
} 
international policing missions. We see a better understanding of trust from the perspective of the police personnel involved as important in terms of learning from these deployments in order to better prepare future personnel and also in deepening appreciation that the realisation of mission objectives is far more complex an achievement than simply "sending the right people properly equipped and with the right set of instructions on what to do." Understandings of trust take us to the relational, non-technical aspects of international policing missions that have received little systematic attention from either policy-makers or researchers to date.

The three countries covered by the research are small states close to Australia with GDP per capita below USD1,400 (World Bank 2011) and low human development (UN 2011). Approximately even numbers of personnel had served in Timor-Leste (65) and Solomon Islands (68), with a smaller number (35) having served in Papua New Guinea (and 15 in other missions not addressed in the interviews). As will be evident from these totals, approximately half of the participants had served in more than one of these locations. At the time of our interviews, Australian police postings in one location were approximately four months before being transferred elsewhere, though often within one mission, personnel might be moved several times. As our data reveals, this represents a challenge to building trustful relationships and the Australian Federal Police (AFP) has moved to longer postings in these kinds of missions.

The missions to these three nations were diverse in many ways. For the purposes of this paper it is useful to point out, briefly, that Papua New Guinea hosted a short-lived ( 8 month) bilateral mission focused on police capacity building; Solomon Islands continues to host a multilateral mission established in 2003 consisting of regional advisors, police and army forces working first to stabilise and then to build capacity in a range of fields including policing; and Timor-Leste has been host to a series of comprehensive United Nations missions, interspersed with stabilising missions under bilateral auspices, with police performing both in-line and capacity building functions.

As might be expected, each of the settings in which our respondents served provided challenging contexts in which to work. The missions in Timor-Leste since 1999 followed a long and violent independence struggle, and institutions such as the police carried an association with Indonesian rule and thus community perceptions of prejudice and oppression (Kingsbury 2009). As one Australian police officer we interviewed reflected that 'some people ... had a lot of anger, residual anger about the military and the police. There was a perception of corruption and that' (R23). Similarly, a key reason for the establishment of RAMSI in the Solomon Islands was the breakdown of law and order and the paralysis of the country's government during the period 2000 to 2003. Inevitably, this had resulted in severe compromises within the Royal Solomon Islands Police (RSIP) in terms of effectiveness, impartiality and legitimacy. Many of the police were identified with one ethnic grouping (Malaitans) during this period, so that member of other groups felt threatened by the police, even if they were not victimised, which many of them were. Hence it is not surprising that the difficulty of building public trust in these environments 
was discussed by many of the Australian officers who served there and encountered the legacy of past policing experiences.

\section{Our respondents' reflections on trust}

\section{Local attitudes towards international policing missions}

In this part we discuss the willingness of local police and people, as seen through the eyes of our respondents, to show trust to each other as well as to international policing personnel. What was clear from our data was that each of the settings considered could be regarded as low-trust settings afflicted by intercommunal distrust and distrust of authorities, both local and international.

For instance, a number of officers who served in the Solomon Islands reported to us that the community there had little trust for the local police at the outset of the mission, and that their first job was rebuilding this trust: 'we were there to maintain a policing presence and also to help start to rebuild confidence in the police themselves' (R24). Knowing how to capitalise upon the high standing of international personnel in the early stages of interventions in ways that work towards, rather than against, restoring confidence in local police is a key issue facing missions seeking to build institutional trust. Recognising this low willingness to trust, many Australian police reported a proactive approach, in which 'we encouraged people [police] to get out amongst it and regain the community's appreciation and understanding through various strategic initiatives' (R29). These tactics were directly towards trust among local police in the international missions :

whilst on patrol if you were going past the hospital or through the markets, we would always have our windows down and ... the kids would come up and jump on the side of the car. If we had any left over ration packs we would - again it's only community policing - give them to the kids, the lollies, or have toys sent over and try to distribute those as equally as we could. You know we did that to the orphanages as well. We would always stop and chat to people, and again, just community policing. Raising your profile, getting known, getting the trust, getting the respect of the people, and engaging them (R29).

Putting a positive face to policing is surely desirable in these settings; however there is likely to be a significant gap between the levels of distrust that have been built up prior to the intervention and the likely returns of a 'smiles and friendly' approach by itself.

One predictable obstacle international police can face is community distrust towards their local police. According to R43, in the Solomon Islands the communities distrusted the RSIP. If you were aligned with the RSIP, you automatically went into that basket, and they'd pull you aside and say "Why are you talking to Sergeant So and So? He did this, this and this. Why hasn't he been locked up?"' The possibility of this negative influence in large measure will be affected by the extent to which the reformed local police still resemble the previous police, one measure of which is the rehiring of police personnel from 
the previous era. The limits of vetting procedures in terms of rooting out personnel with negative associations to the previous era have been apparent in the case of Timor-Leste as well. Where, as often will be the case, the international police do not control or cannot always veto those readmitted into the reconstituted local police forces, there will be consequences both for how the international police presence is regarded and the prospects for establishing a more trustworthy local police.

As part of a reform push, there will be limits to what can be established in terms of trust between international and local police, especially those in the latter category who face vetting for readmission or who are subject to new methods and changes in the power distribution in the new arrangements. While there are signs in some quarters of an 'international brotherhood' developing among police from different countries (Deflem 2002), there are few signs of a ready affinity here. Our data suggests that the extent of a 'brotherhood' developing across international policing missions and with local police remains limited, and the possibility of its achievement under mission conditions a moot point. As we have noted elsewhere (Goldsmith and Harris 2009), Australian police serving on multilateral peace-keeping missions in Timor-Leste did not always experience this anticipated support from other police forces, and this created a difficult working environment.

Often, international police will have to contend with divisions within local police forces. Distrust among local police will often not be well understood in advance of deployments. It will also affect relations between international and local police. Ethnic tensions within the local police in the Solomon Islands constituted a real difficulty, as described by R55:

\footnotetext{
you could sort of see the underlying mistrust between some of the police, you know, about the Guadis not trusting the Malaitians, but still working alongside them and having jokes with one another and - but you knew sort of deep down they probably didn't really trust them, and some of them held resent from what had happened during the tensions, during the $2000-$ when they had the murders and that ... Now this person hadn't been brought to justice, but they're still working with them. But I guess they knew that while the RAMSI's there ... it's not going to blow up again... [but] they didn't really trust them, or they harboured this resentment
}

In Timor-Leste, divisions emerged along 'Eastern' and 'Western' lines in 2005 and 2006 within the police force as well as the military and other institutions of government, that proved to be highly destructive to mission goals of building public confidence in the local police and its ability to provide an effective, professional service to the people. In Papua New Guinea there were observed divisions between those who wanted change and those who did not. In short, the terrain for trust-building within local police forces is often fractious and contested, a fact that demands better preparation but that must also temper expectations around choice and realisation of mission goals.

As a local police officer, there can be risks in being seen to be 'too close' to international personnel. Reformers always face risks when tackling the status quo, and international policing contexts prove to be no exception. As R45 
reflected on the situation in Papua New Guinea, 'probably one of my biggest concerns [was] what's going to happen with those officers who had supported us [while we were there], when it was obvious that there were other officers out there running their own race and obviously ... didn't want us there and still continued to go about doing what they wanted to do even though we were there.' While changes in administration usually produce some casualties, the uncertainty surrounding the length and success of international policing deployments means that local police officers will be taking major risks to themselves in aligning themselves too closely with mission personnel and objectives. Some will try to 'play both sides of the street' while many will practise forms of non-compliance or provide only limited cooperation. The answer to this dilemma, whatever it may be, clearly lies beyond the competence of individual international police personnel in particular relationships with local police. Ways of supporting local reform-inclined police will be needed that reduce the local risks they face. Securing local high-level endorsement for mission objectives methods is therefore likely to be crucial in the longer-term for allowing trust to develop.

\section{Trust-building with local police}

In this section, we consider the approaches Australian police took to building individual relationships in their work settings. Elsewhere in the development literature scholars have pointed to the critical role that relationships play in capacity building (see Girgis 2007; Kaplan 2000). One of our respondents,R5, echoed this, stating that 'I just found myself being frustrated about [various] things and, of course, it's one thing to say that but then the other side of the equation is to actually capacity build people to think of those things as well, and before you can do that you have to relationship build so they'll at least work with you in doing the processes.'

In their work to influence the practices of local police, Australian police adopted a range of tactics to demonstrate their trustworthiness. Prime amongst these was 'get[ting] your hands dirty' (R54) - that is, showing that they were willing to do the work too. This was particularly relevant in Papua New Guinea, where 'we were supposed to be advisers. We weren't supposed to be helping them with all the paperwork,' but as R24 discovered, 'we felt a bit guilty sitting on our arse doing nothing, so we helped start with some of the paperwork and that's what helps form a better bond and friendship with our counterparts. Because we were prepared to do some of the other work with them not just watch.' Of course, as an example of a familiar paradox in capacity-building, by getting involved directly in police work as part of the process of building trust, the goal of building capacity at the local level risks being compromised.

A variety of expectations around relationship building were revealed by the data. It is noteworthy that few respondents appeared to anticipate difficulties in setting up working relationships. It seemed to surprise many of the police we interviewed that they had to build relationships from the ground up with their local colleagues, and 'show you're worthy of respect' (R53). On the other hand, 
several interviewees noted that they couldn't assume that they started from a point of mutual respect. As R16 reflected, 'You can't be expected to win them over in a day because they're very wary of you and the way you are.' R6 conceded that:

there was a lot of resistance from the police at that police station in relation to the people coming in. So it was about breaking down barriers initially you know. And trying to get them all on side, the police we were working with, before we could actually start working with them ... and the way to do that was to create friendships. That is the way I saw it anyway. It certainly wasn't to go in there with a big stick and wave it around, it was to create an environment of trust.

What trust-building meant to our respondents was not an issue we directly sought data on. However some indications emerged from our interviews. The importance of showing, and getting, respect, was mentioned by several respondents. 'It goes back to that thing about gaining their respect, and they won't tell you things unless they respect you' (R40 SI). Such respect was seen as contributing to a personal desire amongst local police to change, with R55 noting, 'I think that when they see how you operate and like I say, if you've got their respect and their trust and they say "Oh yeah, that's - I see why you did that" or they look up to you and they try and emulate you'. It also created a relationship in which respectful critique could be given and responded to, in that 'you go in, look, listen, learn and once you get the relationship going then you might - then you'll be able to offer some suggestions' (R49).

Hardly surprisingly, establishing workable relationships among police could often prove difficult. Just as the relationships with communities were fragile and changeable, relationships with police counterparts could be interrupted or derailed. Here, the impact of short rotations was evident. As R73 pointed out, mistakes could be very costly in terms of achieving the desired capacity building outcomes:

Anyone can ride anyone out for fifteen weeks ${ }^{3}$. If they don't like you, they will just, they are a bit like snails, they will crawl back into their shell, sit and ride the storm out, when you leave, they pop their head out and think, 'right I wonder if I will get on with the next guy?' Understanding that and then coping and dealing with, you know. Making an effort to develop the relationship so that they don't crawl into their shells and turn off while you are there and just ride you out, um is probably the biggest, connecting with them is probably the hardest thing.

A distinction was drawn at times by our respondents between trust in the context of professional relationships and personal relationships. Indeed, the latter was seen by some respondents as a precondition for the former, at least in these settings where there is typically less inclination to draw or see a bright line between the two realms. Our respondents spoke of the importance of building personal relationships with the people with whom they work most closely. In many mission environments, separating professional from personal relationships is not just difficult; it can appear to undermine mission objectives. This personal aspect included finding out about their families and communities,

\footnotetext{
${ }^{3}$ At the time of the interviews (2005-7), officers were generally deployed in three month rotations, followed by a one month break and redeployment to a different posting.
} 
and acknowledging the cultural demands on them - as for example when culture would demand that an officer not confront a community member due to personal ties, which R21 addressed by giving local colleagues the opportunity to step down from particular cases where such conflict arose. Equally important was taking a genuine personal interest in their colleagues - indeed, according to R29, 'you could not have anything but a personal relationship with the RSIP. To try and keep a strictly professional arm's length would not have worked. They are a very personalised people.'

Examples of this included the obvious approach of asking about their family members and their life outside work, as well as less obvious ones like helping a colleague to fill in bureaucratic paperwork needed to enable a family member to travel to Australia for a funeral (R5). In fact, R54 noted that you build trust in Solomon Islands the same way 'you do it anywhere else. Guys you work with, drink with, you talk with, you socialise with ... [and] You don't speak down to them.'

Trying to deal with the blurring of the professional and the personal confronted some respondents with acute dilemmas from time to time. At these moments, the lack of convergence between local and mission values became vivid and a real obstacle to relationship building. This was particularly highlighted in situations whre Australian officers felt forced to choose between building trusting relationships with particular officers and compromising foundational Australian policing values. A vivid example of this was local police wanting to use police missions to gather food, for example by fishing from the police boat, or using police vehicles for personal purposes. R46 explained some of the aspects of this dilemma as follows:

there are a lot of pressures on the police officers to [support their families and kinship groups], and how can you say no? ... Like how do you say, no you can't bring your fish back for your starving family; you'll have to work out some other way. It's just that, those things I found a little bit confronting at times because you have to try and keep the peace I suppose because if you said no, ... they would probably just not have a good relationship with me any more, so you have to draw the line somewhere ... It's very easy for us to say, but for the local police they could never understand why you took that stance.

Learning how to juggle these circumstances is a real operational challenge for many international policing personnel. While there will often be no clear or at least easy answers to these dilemmas, this type of challenge suggests that more could be done to prepare international police to anticipate such challenges arising through cultural awareness training, ethical role-plays and other devices, and to provide them with a range of tactics for managing them.

Having a significant personal relationship with local police could at times enable the assurance that internationally endorsed policing standards were not breached in particular circumstances by local police. R6, who served in Papua New Guinea, explained that once trust was established, there could be quite frank discussions about behavioural change:

there was [a philosophy] to shoot first and ask questions later and we would go to a specific task were there was a possibility that there would be shootings, so and I 
would implore these guys, okay we are not to shoot unless they shoot at us, ... [so] you would have to impress upon them the importance of not killing anybody especially while we were there because we would get the blame and you know if you had any respect for us, you wouldn't do it and that's were that friendship and trust and that built up to a point and they would go okay, well we are not going to kill anyone, we won't shoot anyone because we don't want you to get into trouble. Not because they don't want to do it, because they just didn't want to get us into trouble so okay.

The sustainability of such positive influences is obviously left open to question by this example. It points to the importance of building effective impersonal controls, as well as relying upon personal influence, if longer-term change is to be sustained and sustainable. Despite the difficulties they encountered, respondents stressed the importance of establishing trusting police-public and peer-peer relationships, and the benefits for both sides of working to achieve this. R61 described this situation aptly in terms of the peacekeeping function, stating that a key goal was for local people to understand that it was safe again in their community. They were not going to be subject to the terrorisation that they had been subject to by the militant groups, that they could walk the street safely, that they could have confidence again in the police.' This quote is a reminder that the capacity to improve very basic requirements of living and social life remains fundamentally important as a means of establishing some trust or trust-like conditions, especially in the early stages of missions.

\section{Trust building with the local community}

Respondents attempted to break down distrust and scepticism locally by demonstrating that Australian police were friendly and trustworthy. The reasons for building trust were practical as well as noble. Achieving a measure of trust, it was viewed, 'encouraged informants, it encouraged community support, we could go to safety levels, we could get our people amongst the community safely, we could start identifying with honing down where the trouble spots were so it has a lot of strategic gains' (R29). It was well recognised that 'engendering that confidence would then start to bring people back in to report crimes that we could then use to support our mission objectives about removing these key people' (R61).

Part of the trust agenda for international missions is building trust in local institutions. A clear example of this was publicly backing up local police. This could mean confronting local power structures and customary hierarchical relationships in the community. R15 noted that 'some of the local VIPs in the village areas didn't respect the young police officers at all ... in that these guys would be ranting and raving and waving their arms at us [but] we'd say, "no, we're not going anywhere", and that probably helped the local police a little bit, in that we weren't intimidated whereas they might have been.' As noted earlier, when local people are more inclined to seek and trust the services of international police personnel over those of local police, putting the local police forward in order to build their capacity may, for international police, mean incurring the wrath of local people. 
The topic of vetting of recruits to the local police can generate difficulties in terms of local perceptions of the effectiveness and impartiality of international police involved in this important aspect of reconstruction and capacity-building. This can occur when prior vetting of new recruits has not been carried out, or has been done hastily and in an incomplete and ineffective manner. ${ }^{4}$ Senior UN Police officers interviewed by the first author in Timor-Leste in late 2006 expressed the view that the attempt by the government there to 'stand up' the PNTL after the 2006 crisis was proceeding too quickly and that sometimes former senior PNTL officers were being 'waved through' without sufficient regard to their criminal actions during the crisis. This knowledge held by international policing personnel, whether in the form of belief or corroborated fact, as R43's observation above perhaps implies, seems likely to influence how police-police relationships are shaped and operate. Perceptions by international police of defective character among senior local police bode badly in terms of being able to establish positive interpersonal relationships and in terms of pursuing capacity-building objectives.

Importantly, local policing practices also impacted on Australian police's disposition towards their counterparts. Often respondents indicated that trusting them was difficult because of their habits and ways of doing police work. These issues are captured by an officer who had served on several missions: especially in Papua New Guinea and I noticed it more in East Timor, the people had a fear of the police. In PNG ... they [police] had no support from up top or anywhere. There was just no guidance. And they wouldn't work so the people sort of had no respect for the police anyway, but they feared them because they knew that if they did the wrong they would get an absolute flogging. What I noticed over the time was they were starting to lose their fear of the police while we were there because the people knew that while we were there the people wouldn't get a flogging and I notice in East Timor, more to the point, the Australia and New Zealanders were sort of known to be soft, where the Portuguese that were there, knew - they - the locals knew that if they mucked up in front of them there would be a scene. (R17)

This description echoes Mastrofski et al's (2002) notion of a vicious cycle of reciprocal disrespect between police and policed in marginalised communities. It also highlights the reality that redressing such cycles is deeply complex. As the previous quotation suggests, there can be a public safety dividend from the restraining co-presence of international police in such circumstances, but one that is ultimately conditional on their ongoing presence rather than any enduring change within the local police force.

Apparent inconsistencies in how international police personnel are treated by local people and police can undermine confidence in the trustworthiness of

\footnotetext{
${ }^{4}$ It is very difficult to find extensive treatment of the police vetting issue in post-conflict settings in the policy or academic literatures. What occurs in practice too often reflects an international desire to restore local policing responsibility quickly, alongside an influential local interest in ensuring that favoured police are returned as soon as possible to the new institution, irrespective of their past misdeeds. As has been seen in Afghanistan and elsewhere, this can have fatal consequences for international police advisers as well as significant costs for others involved.
} 
locals. Such perceptions often led international police to question their own methods as well as whether the mission goals were indeed appreciated or shared among the local population. This could justify a stance of caution and distrust on the part of international police personnel. Setbacks in the security situation perversely but somewhat understandably appeared to do significant damage to Australian police's trust in the public. R16 reflected that police had to remain on their guard and not assume that they had achieved positive relationships, stating that 'In East Timor one minute, like, they're changing your car tyre and the next minute they're [throwing rocks at] you. So ... you don't trust the people.' This unpredictability or inconsistency could contribute to a stressful environment for officers who were used to being able to judge relationships and the dynamics of policing more accurately in Australia (Goldsmith 2009).

Similarly, in the case of the large-scale civil disturbances in both the Solomon Islands and Timor in 2006, Australian police felt betrayed by the public, in that they were not informed of the pending unrest by any of their informants. R29 discussed this clearly, saying,

The only difficulty came after the riots where you couldn't cross the personal [inaudible] the major balance of society that was rioting and causing problems by stoning you and throwing machetes at you and so on and so forth. So the problem was it was great up to the riots and a significant amount of respect and trust was lost post riots and you never knew who you trusted, therefore it took a long time to rebuild the confidence to trust locals, because during the riots you felt that everybody was against you.

While feelings of betrayal and disappointment were evident, from a mission accomplishment and operational point of view, the question arises of how these feelings influence subsequent dealings with local police and members of the public. A robustness of attitude, informed by a tragic view of the possibilities of change in particular settings, would not seem inappropriate, and even could be seen as desirable or a necessary survival skill for overseas service. Muir (1983, 7) describes the tragic view as "a philosophy which holds that good and bad inhere in each of us, that self-control is an important but not exclusive determinant of man's fate, and that life is meaningful only if we give a damn about others, no matter how such concern hurts." It is, Muir indicates, an antidote to the cynicism that too readily can emerge in police officers. Meeting local distrust with distrust from members of the mission seems certain to further undermine existing relationships and the pursuit of mission objectives. Our respondents, encouragingly, showed little evidence of any resentment impacting on their actions. In dealing with and building trust from the public, they arguably demonstrated both commitment and forbearance. Despite setbacks, they continued to work in this way - if perhaps more warily than before.

Demonstrations of forbearance, as indicated by tolerance of differences of values and approaches, were evident in several of our respondents' answers. Regarding Timor-Leste, R58 spoke of the persistent determination sometimes required to maintain this approach:

I treat people with dignity and respect ... so I don't ever recall thinking "I'll never get through to these people or whatever", there were - of course there were 
moments of frustration where I didn't understand what was going on or things that they wanted were in conflict to things that I needed to do, but that's just you've just got to go with that. You've just got to tolerate that. That's what missions are all about. You're never going to get everything you want, it's never going to happen in the time that you expect it to, and you just have to deal with the contingencies.

A degree of fatalism (a tragic view) is evident in such remarks. An acceptance of difficulty in the job enables work to continue in part through making allowances for perceived shortcomings in the actions and attitudes of others.

Finally, in terms of building trust with local police and local people, it should be noted that the very premises upon which international policing missions are undertaken lend themselves to making it difficult for international policing personnel to respect or trust local police and for local people to willingly trust either their own police or, at times, the international police. After all, it is due to a perceived breakdown in local security capacity or need for significant change that brings international police into these settings, yet very often, local expectations of international police are disappointed for various reasons including insufficient understanding of local circumstances and inadequate resources for dealing effectively with pressing problems. It is not surprising then that many international police will bring with them assumptions about the limited competence of local police as well as the fickleness of local people which can restrict demonstrations of respect towards counterparts and the community.

Starting with the assumption that local officers are generally incompetent, or that the majority of the local population can't be trusted, amount to obstacles to establishing trust. A willingness to trust presumptively indeed may be a prerequisite for securing trust in these circumstances. Against this idea, many of our respondents admitted to holding a generally negative perception of local capacity, identifying their particular counterparts as exceptions to this rule (see Harris 2010). The fact that some respondents were able to distinguish their immediate counterparts from a more generalised negative assessment at least leaves open ways of working constructively with local counterparts. In future efforts to build interpersonal trust, further thought needs to be given to identifying and establishing forms of reciprocity of recognition between international and local people, so that differences that emerge in the life of missions can be managed positively rather than being assumed by one party to be indications of weakness by the other.

\section{Conclusion}

[F]or us it was about re-establishing that community confidence. It is getting them to understand that it was safe again in their community. They were not going to be subject to the terrorisation that they had been subject to by the militant groups, that they could walk the street safely, that they could have confidence again in the police and engendering that confidence would then start to bring people back in to report crimes that we could then use to support our mission objectives about removing these key people (R61). 
As this quotation indicates, ensuring conditions of public safety is fundamental to the enjoyment of individual freedom and cultural identity. Paradoxically, trust in police is often elusive when it is most needed in order to make restoration of public safety achievable. This paper has taken for granted the general value of there being trust in international policing mission settings between mission personnel, local police and people. Our data confirmed that this assumption was widely shared by our respondents. For them in general, it can be said, understandings of trust were crucial to how they approached their work and made sense of their experiences. Nonetheless, as the analysis of the data makes clear, often trust as a characteristic of interpersonal relationships and contacts is an ideal or an illusion, rather than a readily achievable objective under the conditions in which international policing missions are typically engaged.

Given the difficulties of establishing trust, more attention is needed to the conditions that facilitate cooperation and collaboration between international policing personnel and local people and police. In other words, identifying forms of positive engagement short of trusting relationships as well as steps on a path to building trust will prove important to improving how these missions work in particular settings in future. Here, collecting complementary data from local people and police is vital. In our study, we did not capture the views of those local police and members of the community with whom they had contact. A more complete dataset would have sought to include their views in order to explore when trust is extended and what features of missions led to greater trustworthiness. It could also have made it possible to directly gauge the different kinds of motivational dispositions towards peacekeeping and capacitybuilding objectives indicated in some of the recent literature (eg Braithwaite et al 2007).

More could be done to prepare international police personnel to anticipate the range of difficulties reported by our respondents, and to provide them with strategies for coping with them. We have seen that many respondents sought to build trust, yet were disappointed in what was achievable. Therefore, in preparing police personnel for future overseas deployments, efforts are needed to ensure that expectations in terms of local reception and cooperation are not unrealistically high. More preparation in terms of the difficulties of achieving quick change and indeed the changes favoured by international police - the tragic perspective - would be beneficial. Also, the inability to communicate with local people remains a common obstacle. Deficits in communicative competence work against practical accomplishments as well as normative convergence, both crucial to establishing trust.

In short, rather on insisting on trust as a measure of achievement or as a necessary tool for making progress, there is a need for more realism. As noted, the instrumentalism seen in some local attitudes and actions should not be surprising. People habituated to distrusting others need material or at least tangible incentives if calculative trust is to emerge. This does not mean that other forms of trust cannot be developed over time. Changing values as well as practices will require a growing normative commitment among local police and local people if these changes are to be sustainable. There are also likely to be 
limits to how much reliance international personnel put on material incentives if an unhealthy, longer-term dependency is not to be created.

Mission time-scales will continue to work against trust-building. There can be little doubt that short rotations work against establishing effective interpersonal trust, especially cognitive and normative trust. In addition to extending rotations (which Australia has done since our interviews), the process of building trust requires more thinking about how to ensure more 'quick wins' and tangible improvements along the pathway of both peacekeeping and capacity-building. As noted, calculative sensibilities among those international policing personnel are working with have to be expected and managed effectively as part of giving effect to the relationships established. Establishing policing services to the most needy and vulnerable in ways responsive to their concerns must therefore be a priority 'on the ground' as well as in mission policy objectives.

Different means for dealing with distrust are also needed. International policing missions as well as the local institutions they are assisting need to subject themselves to a regulatory environment that is conducive to establishing trust. In short, institutional trust through accountability (eg an independent complaints authority) and measures of responsiveness (eg local level community safety committees) need to be established publicly as part of the strategy of building trust more generally in police-community relations. Responding to distrust implies a number of other steps, including patience and forbearance, and a commitment from the beginning to negotiate expectations around the mission.

In the end though, international policing missions engaged in peacekeeping and capacity-building will continue to take place in environments in which social disengagement from central government is commonplace, and in which broader social trust is scarce or non-existent. It is also the case, as we have seen, that failures at the strategic level (institutional trust) will inevitably impact upon operational achievements (interpersonal trust). Factors that impact upon the trustworthiness of government and political institutions generally, as well as the police in particular, will affect what can be achieved operationally in interpersonal trust in policing mission settings. Given these realities, there is relatively little that international policing missions can achieve by way of building trust and public confidence either quickly or by themselves. We need therefore to recognise the complexity of building trustworthy policing arrangements, important as they remain, and to avoid glib talk about trust until the challenges are better understood and begin to receive broader contextual support. Inevitably, the final responsibility for overcoming disengagement and defiance, and for building trustworthy police agencies, rests mainly with the local, national, regional, and international political systems and the communities in which they are located. 


\section{Bibliography:}

Bellamy, Alex, Williams, Paul and Griffin, Stuart. 2006 Understanding Peacekeeping. Cambridge: Polity Press.

Braithwaite, Valerie, Kristina Murphy, and Monika Reinhart 2007. "Taxation threat, motivational postures, and responsive regulation" Law \& Policy, 29(1), 137-158

Brenkert, George. 1998. "Trust, Morality, and International Business" in Lane and Bachmann, eds, Trust Within and Between Organizations. Oxford: Oxford UP. 273-297

Burt, R. 2001. "Bandwith and echo: trust, information, gossip in social networks" in J Rauch and A Cassella, eds. Networks and Markets, Russell Sage, New York. 30-74

Chase, Susan. 2005. "Narrative Inquiry: Multiple Lenses, Approaches, Voices." In The Sage Handbook of Qualitative Research, eds. Norman Denzin and Yvonna Lincoln. London: Sage.

Child, John. 1998. "Trust and International Strategic Alliances: The Case of SinoForeign Joint Ventures" in Christel Lane and Reinhard Bachmann, eds, Trust Within and Between Organizations: Conceptual Issues and Empirical Applications. Oxford: Oxford UP

Chesterman, Simon. 2004. 'You the People': The United Nations, Transitional Administration, and State-building. New York: Oxford.

Cherney, Adrian and Murphy, Kristina. 2011. "Understanding the contingency of procedural justice outcomes" Policing, [advance access, 22 July 2011]

Choong, Satnam. 1997, Policing as Social Discipline Oxford: Clarendon Press

Das, TK and Rajesh Kumar 2009. "Interpartner harmony in strategic alliances: managing commitment and forbearance" International Journal of Strategic Business Alliances, 1 (1), 24-52

Das, TK and BS Deng 2000. "Instabilities of Strategic Alliances: An Internal Tensions Perspective" Organization Science, 11 (1), 71-101

Deflem, Mathieu. 2002. Policing World Society. Oxford: Oxford UP

Denzin, Norman and Yvonna Lincoln eds. 2005. The Sage Handbook of Qualitative Research. London: Sage.

Dinnen, Sinclair and John Braithwaite. 2009. "Reinventing policing through the prism of the colonial kiap" Policing \& Society, 19 (2), 161-173

Fukuyama, Francis. 1995. Trust: The Social Virtues and the Creation of Prosperity. New York: Free Press.

Gambetta, Diego. 1988. "Can we trust Trust?" in Gambetta, ed. Trust: Making and Breaking Cooperative Relations. Blackwell, Oxford.

Girgis, Mona. 2007. "The Capacity-building Paradox: Using friendship to build capacity in the South." Development in Practice 17(3):353-366.

Goldsmith, Andrew. 2003. "Policing Weak States: Citizen Safety and State Responsibility" Policing \& Society, 13, 1, 1-21

Goldsmith, Andrew. 2005. "Police Reform and the Problem of Trust" Theoretical Criminology, 9(4), 443-470

Goldsmith, Andrew. 2009. "'It wasn't like normal policing: Policing \& Society, 19, 119-133 
Goldsmith, Andrew and Sinclair Dinnen. 2007. "Transnational policebuilding: critical lessons from Timor-Leste and Solomon Islands" Third World Quarterly, 28(6), 1091-1109

Goldsmith, Andrew and Vandra Harris. 2009. "Out of Step: Multilateral police missions, culture and nation-building in Timor-Leste." Conflict, Security and Development 9(2):189-211.

Harris, Vandra. 2010. "Building on Sand? Australian police involvement in international capacity building." Policing and Society 20(1):70-98.

Hough, Mike, Jackson, Jonathan, Bradford, Ben, Myhill, Andy, and Quinton, Paul. 2010. "Procedural Justice, Trust, and Institutional Legitimacy" Policing, 4 (3), 203-110

Jackson, Jonathan and Bradford. 2010. "What is Trust and Confidence in the Police?" Policing, 4 (3), 241-248

Jones, Bruce, Richard Gowan, Jake Sherman (2010), "Excerpts from 'Building on Brahimi: Peacekeeping in an Era of Strategic Uncertainty" in Center for International Cooperation, Robust Peacekeeping: The Politics of Force (New York: CIC, New York University)

Kaplan, Allan. 2000. "Capacity building: shifting the paradigms of practice." Development in Practice 10(3 \& 4):517-526.

Kingsbury, Damien. 2009. East Timor: The Price of Liberty. New York: Palgrave Macmillan.

Lane, Christel. 1998. "Introduction: Theories and issues in the study of trust" in Lane, Christel and Reinhard Bachmann, eds, Trust in and between Organizations: Conceptual Issues and Empirical Applications. Oxford: Oxford University Press, 1-30

Luhmann, Nicholas. 1988. "Familiarity, confidence, trust: Problems and alternatives" In Gambetta, ed. Trust: Making and Breaking Cooperative Relations. Blackwell, Oxford. 94-107

Mastrofski, Stephen, Michael Reisig, and John McCluskey. 2002. "Police Disrespect Toward the Public: An Encounter-Based Analysis" Criminology. 40 (3), 519-552

Misztal, Barbara 1996. Trust in Modern Societies. Cambridge: Polity Press.

Montgomery, Kathleen, Jordens, Christopher, and Little, Miles. 2008. "How vulnerability and trust interact during extreme events: Insights for Human Service Agencies and Organizations" Administration \& Society, 40, 621-644

Muir, William Ker. 1983. "Police and Politics" Criminal Justice Ethics, 2, 3-9

Neocleous, Mark . 2011. "The Police of Civilisation: The War on Terror as Civilizing Offensive" International Political Sociology, 5, 144-159

Odello, Marco. 2010. "Tackling Criminal Acts in Peacekeeping Operations: The Accountability of Peacekeepers" Journal of Conflict \& Security Law, 15(2), 347-391

Open Society Justice Initiative. 2009. Ethnic Profiling in the European Union: Pervasive, Ineffective and Discriminatory (New York: OSJI)

Parker, J Nealin (2010) "Robust Peacekeeping: The Politics of Force Introduction" in Center on International Cooperation, Robust Peacekeeping: The Politics of Force (New York: CIC, New York University) 2-6

Putnam, Robert. 1993. Making Democracy Work. Princeton: Princeton University Press

Reiner, Robert. (2010). The Politics of Police, $4^{\text {th }}$ ed Oxford: Oxford UP. 
Sharp, Elaine and Johnson, Paul. 2009 "Accounting for Variation in Distrust of Local Police" Justice Quarterly, 26 (1) 157-182

Skogan, Wes. 2006. "Asymmetry in the Impact of Encounters with Police" Policing \& Society, 16(2), 99-126

Smith, Sandra. 2010. "Race and Trust" Annual Review of Sociology, 36, 453-475.

Stabilisation Unit. 2009. Stabilisation QIPs Handbook. London: Stabilisation Unit

Tankebe, Justice. 2009. "Public Cooperation with the Police in Ghana: Does Procedural Fairness Matter?" Criminology, 47 (4), 1265-1293.

Thomas, Craig. 1998. "Maintaining and restoring public trust in government agencies and their employees" Administration \& Society, 30, 166-193

Tranter, Bruce, and Skrbis, Zlatko. 2009. "Trust and confidence: A study of young Queenslanders" Australian Journal of Political Science, 44 (4), 659-678

Tyler, Tom. 1990. Why People Obey the Law: Procedural Justice, Legitimacy and Compliance. New Haven: Yale University Press

Weitzer, Ron. 1995. Policing Under Fire: Ethnic Conflict and Police-Community Relations in Northern Ireland Albany: State University of New York Press

United Nations. 2011. Human Development Report 2011: Sustainability and Equity - A Better Future for All. New York: United Nations

Vangen, Siv, and Huxham, Chris. 2003. "Nurturing Collaborative Relations" Building Trust in Interorganizational Collaboration" Journal of Applied Behavioural Science, 39, 5-31

World Bank. 2011. World Development Report. Washington DC: World Bank

Zhang, Ying and Huxham, Chris. 2009. "Identity Construction and Trust Building in Developing International Collaborations" Journal of Applied Behavioral Science, 45, 186-211 